\title{
Angewandte
}

Supporting Information

\section{A Single Atom Change Facilitates the Membrane Transport of Green Fluorescent Proteins in Mammalian Cells}

Surendar R. Jakka, Vijayakumar Govindaraj, and Govindasamy Mugesh*

anie_201902347_sm_miscellaneous_information.pdf 


\section{Table of Contents}

SI No.

Contents

Page No.

1. Experimental Procedure

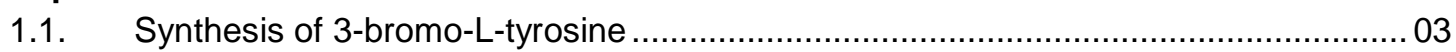

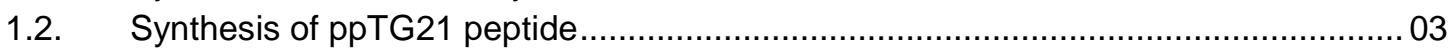

1.3. Plasmid construction, Protein Expression and Purification....................................... 04

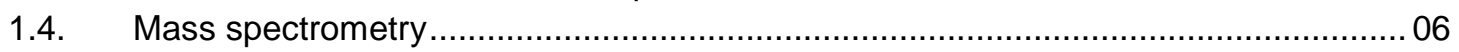

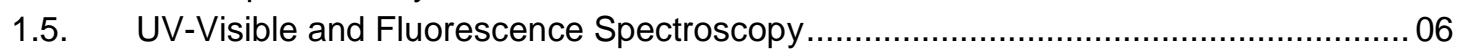

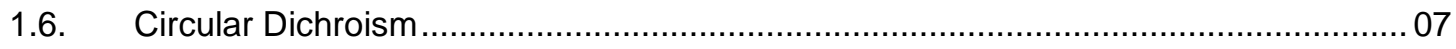

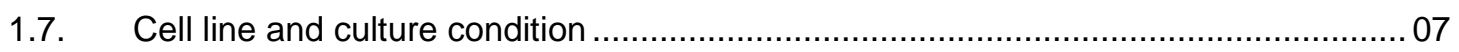

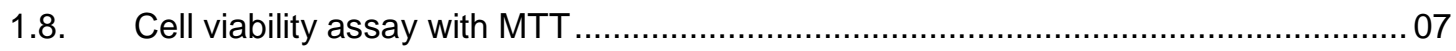

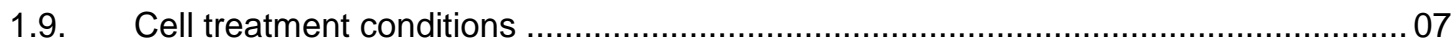

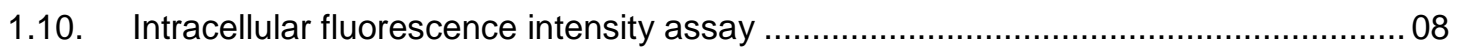

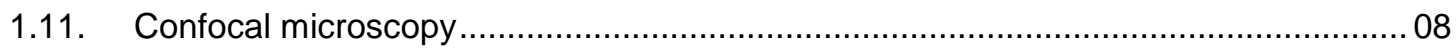

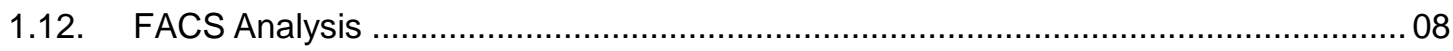

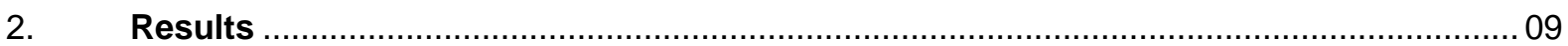

2.1. Characterization of 3-bromo-L-tyrosine by ${ }^{1} \mathrm{H}$ and ${ }^{13} \mathrm{C}$ NMR (Figure S2-S3) ............. 09

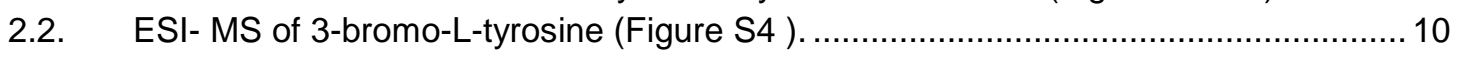

2.3. HPLC chromatogram of ppTG21 peptide (Figure S5 ) ........................................ 10

2.4. Mass spectra of WT-, 1TAG- and 2TAG-3-halo-Y-EmGFP (Figure S6-S10) ............. 11

2.5. FACS analysis of HepG2 cells treated with halo-Y-EmGFP (Figure S11) ................ 16

2.6. Confocal images of HepG2 cells treated with various concentrations of halo-Y-

EmGFP (1TAG) (Figure S12) ...................................................................... 17

2.7 Plate reader assay and confocal images of HepG2 cells treated with 1TAG-3IY

EmGFP after co-treatment with 3-iodo-L-tyrosine (Figure S13) ............................. 19

2.8. Confocal images of halo-EmGFP (1TAG) in HepG2 cells after various treatment conditions (low temperature, ATP depletion, MCT8 inhibitor or endocytosis inhibitors)

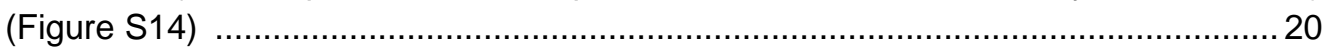

2.9. Confocal images of HepG2 cells treated with various concentrations of halo-EmGFP

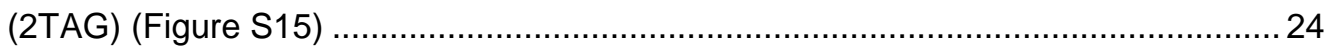

2.10. Confocal images of halo-Y-EmGFP (1TAG) in HepG2 cells after various treatment conditions (low temperature, ATP depletion, MCT8 inhibitor or endocytosis inhibitors)

(Figure S16).....

2.11. Confocal images of HepG2 cells after co-treatment with halo-Y-EmGFP and ppTG21 peptide (Figure S17)

2.12. Plate reader assay and confocal images of HepG2 cells with 1TAG-3IY EmGFP with co- and post-treatment with ppTG21 (Figure S18)

2.13. Co-localization of 1TAG-3IY and plasma membrane marker (WGA) in the absence and presence of ppTG21 (Figure S19-20)

2.14 Confocal images of HepG2 cells after 90 min of treatment with $1 \mu \mathrm{M}$ 1TAG-3IYEmGFP from two different cell fixing conditions (Figure S21) 


\section{Experimental procedure}

\subsection{Synthesis of 3-bromo-L-tyrosine}<smiles>NC(Cc1ccc(O)cc1)C(=O)O</smiles>

L-Tyrosine

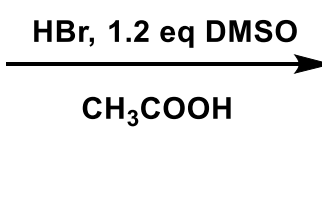

3-Bromo-L-Tyrosine

Scheme S1. Synthesis of 3-bromo-L-tyrosine. ${ }^{[1]}$

L-Tyrosine (1.0 g, $5.5 \mathrm{mmol}$ ) was suspended in $10 \mathrm{~mL} \mathrm{AcOH}$, and $2.4 \mathrm{~mL} 48 \% \mathrm{HBr}(21.6 \mathrm{mmol})$ was added. Then, $480 \mu \mathrm{L}$ DMSO (6.6 mmol) was added, and the colorless suspension immediately turned yellow-orange. The suspension was warmed to $65^{\circ} \mathrm{C}$ for $2 \mathrm{~h}$, giving a clear light-yellow solution. It was then removed from the heat and the stirring was continued at $27^{\circ} \mathrm{C}$ for $8 \mathrm{~h}$. The clear yellow solution was then evaporated under reduced pressure to give a white solid, which was dissolved in 10 $\mathrm{mL}$ hot water, the $\mathrm{pH}$ was adjusted to 6 with solid $\mathrm{NaHCO}_{3}$, and the product was crystallized at $4{ }^{\circ} \mathrm{C}$. The crystalline suspension was filtered, the white crystals were washed with cold water and dried. A few more crystals were obtained from the filtrate upon standing. Yield: $935 \mathrm{mg}(65.2 \%),{ }^{1} \mathrm{H}$ NMR: $\left(\mathrm{D}_{2} \mathrm{O}\right) \delta 7.27(\mathrm{~d}, 1 \mathrm{H}), 6.99(\mathrm{dd}, 1 \mathrm{H}), 6.82(\mathrm{~d}, 1 \mathrm{H}),, 3.76(\mathrm{dd}, 1 \mathrm{H}), 3.01(\mathrm{dd}, 1 \mathrm{H}), 2.88(\mathrm{dd}, 1 \mathrm{H})$; MS(ESI): 260.98.

\subsection{Synthesis of ppTG21 peptide}

A literature method was used with modifications. ${ }^{[2]}$ The ppTG21 peptide was synthesized by standard Fmoc-based solid phase synthesis using microwave assisted automated peptide synthesizer Liberty 1 from CEM. The synthesis was performed on a $0.1 \mathrm{mmol}$ scale using Rink Amide MBHA resin. The resin $(270 \mathrm{mg}$ ) was swollen in $10 \mathrm{~mL}$ DMF for $1 \mathrm{~h}$ prior to the synthesis. For each coupling reaction, a 5 -fold excess of reagents $(2.5 \mathrm{~mL}$ of $0.2 \mathrm{M} \mathrm{Fmoc}$ protected amino acid, $1.0 \mathrm{~mL}$ of $0.5 \mathrm{M} \mathrm{DIC}$ and 0.5 $\mathrm{mL}$ of $1 \mathrm{M} \mathrm{HOBt}$ solutions in NMP) were used. The side chain protecting groups used for His, Ser and Trp were Trityl (Trt), ter-Butyl (tBu) and ter-Butoxycarbonyl (Boc) respectively. All the coupling reactions except that of His were performed for 2 min with maximum temperature of $90{ }^{\circ} \mathrm{C}$ as has been reported earlier. ${ }^{[2]}$ The His residues were coupled at a lower temperature of $50{ }^{\circ} \mathrm{C}$ for 6 min and the coupling was repeated twice with fresh reagents each time. Deprotection of the Fmoc group was achieved by $20 \%$ Piperidine in DMF $(7 \mathrm{~mL})$ for $30 \mathrm{sec}$ followed by 3 min with a maximum temperature of $75{ }^{\circ} \mathrm{C}$. The peptidyl resin was washed thoroughly with $\mathrm{DCM}(10 \mathrm{~mL} \times 3)$ after completion of the synthesis. Cleavage of the peptide from the resin was performed manually by shaking at $27^{\circ} \mathrm{C}$ for $2 \mathrm{~h}$ using the cleavage cocktail $(8 \mathrm{~mL}$ ) comprising of $92.5 \%$ TFA , $2.5 \%$ TIS , $2.5 \%$ DODT and $2.5 \%$ water. The resin was filtered and washed with $2 \mathrm{~mL}$ of fresh cleavage cocktail and the combined filtrate containing the cleaved peptide was collected. The peptide was precipitated from the cleavage 
cocktail solution by adding ice-cold diethyl ether. The precipitate was collected by centrifugation, dried under reduced pressure, dissolved in 50\% acetonitrile in water and lyophilized the crude and lyophilized peptide was purified reverse phase HPLC using Waters semipreparative HPLC system comprising of Waters 1525 binary pump and Waters 2489 UV/Visible detector. A semipreparative column from Phenomenax (Gemini Nx-C18; $5 \mu \mathrm{M} ; 110 \AA 150 \times 10 \mathrm{~mm}$ ) was used with a flow rate of 1 $\mathrm{mL} / \mathrm{min}$. A linear gradient of $10 \%$ B to $90 \%$ B over 60 min was applied where solvent $A$ was $0.1 \%$ TFA in water and solvent $B$ was $0.1 \%$ TFA in acetonitrile. The purity of the peptide was determined to be $98 \%$ by analytical HPLC. The peptide was further confirmed by MALDI (Expected Mass -2340.86 Observed Mass - $\left.2341.0(\mathrm{M}+\mathrm{H})^{+}\right)$.

\subsection{Plasmid construction, Protein Expression and Purification}

Plasmid that can site specifically insert 3-iodo-L-tyrosine (3IYRS) in response to amber codon was generated from pEVOL-uaa (a gift from Prof. Peter G. Schultz, The Scripps Research Institute, Figure S1A). pEVOL plasmid contained one copy of tRNAcuA ${ }^{\text {opt }}$ and two copies of the evolved M. jannaschii tyrosyl-tRNA synthetase (aaRS) for L-(7-hydroxycoumarin-4-yl) ethylglycine, one of which was under an arabinose promoter and another under a constitutively activated glnS' promoter. ${ }^{[3,6]}$ The second copy of aaRS including glnS' promoter was replaced with cassette having Emerald GFP under t5 promoter. The cassette was amplified with primers 11-12 (Table S2). Similarly, pEVOL-uaa vector backbone excluding the aaRS copy under gInS' promoter was amplified with primers 9 \& 10 (Table S2). Both pEVOL vector backbone and EmGFP cassette (provided by Prof. Umesh Varshney, IISc) were ligated by using NEBuilder ${ }^{\circledR}$ HiFi DNA Assembly Cloning Kit (E5520S). The clones were confirmed by DNA sequencing.

Table S1: List of oligos used for this study.

\begin{tabular}{|c|c|c|}
\hline S. No. & DNA Oligo name ${ }^{\#}$ & Sequence $\left(5^{\prime}-3^{\prime}\right)$ \\
\hline 1 & MjTyrRS32Alafp new* & TATAGGTTTTGAACCAAGTGG \\
\hline 2 & MjYRS 32Tyr rpNO new & TAAGCAGATTTTTCATCTTT \\
\hline 3 & mjYRS 65 Leu rp NO & GGCCAACAATATAATTATATCAAATCCAG \\
\hline 4 & MjYRS70AlafpNew & GATTTAGCCGCCTATTTAAACCAG \\
\hline 5 & MjYRS108F109Qfp new & TTTCAGCTTGATAAGGATTATACAC \\
\hline 6 & MjYRS108109rpNO new & TTCACTTCCATAAACATATTTTG \\
\hline 7 & mjYRS158ThrrpNO new & CGTATTAACCTGCATTATTGGATAGATAAC \\
\hline 8 & mjYRS159Serfp new & TCTCATTATCTTGGCGTTGATGTTGCAGTTGG \\
\hline 9 & EmGFPpromo-pEVOLrp & GGCCTCGTGATTTGATAATCTAACAAGGATTATG \\
\hline 10 & EmGFP-pEVOLfp & TGGTGAGAATCTGCAGTTTCAAACGCTAAATTGC \\
\hline 11 & pEVOL-EmGFPPromfp & ATTATCAAATCACGAGGCCCTTTCGTCTTC \\
\hline 12 & pEVOL-EMGFPrp & TGAAACTGCAGATTCTCACCAATAAAAAACGCCC \\
\hline 13 & EmGFPY39Amfp & GGGCAAGCTGACCCTGAAG \\
\hline 14 & EmGFPY39AmrpNO & TAGGTGGCATCGCCCTC \\
\hline 15 & EmGFP K214Am fp & CCAACGAGTAGCGCGATCAC \\
\hline 16 & EmGFP K214Am rp NO & GGTCTTTGCTCAGGGCGG \\
\hline
\end{tabular}

"DNA Oligo =Primer; ${ }^{*}$ DNA oligo used as common forward primer with Non-overlapping reverse primer to get mutations such as 32 Tyr, 32 Gly

The resultant plasmid subjected to site-directed mutagenesis based on known active site mutations reported (Table S1) ${ }^{[4]}$ to achieve a synthetase that can charge 3-iodo-L-tyrosine. The site 
directed mutagenesis was carried out with $\mathrm{Q}^{\circledR}{ }^{\circledR}$ Site-Directed Mutagenesis Kit (E0554S from NEB), and primers 1-8 (Table S1) were used. The final clones were confirmed by sequencing the constructs (Figure S1B).

Table S2: List of mutations in the synthetases Cou-Etglycyl and 3IYRS.

\begin{tabular}{|c|c|c|c|c|c|c|c|c|c|c|}
\hline \multirow{2}{*}{ Synthetase } & \multicolumn{9}{|c|}{ Position } & \multirow{2}{*}{ References } \\
\cline { 2 - 12 } & 32 & 65 & 67 & 70 & 108 & 109 & 158 & 159 & 162 & \\
\hline Tyrosyl (native) & Tyr & Leu & Ala & His & Phe & Gln & Asp & Ile & Leu & {$[5]$} \\
\hline Coumaryl & Glu & His & Gly & Gly & Tyr & His & Gly & & Gly & {$[6,3]$} \\
\hline 3-iodo-tyrosyl & & & Ala & Ala & & & Thr & Ser & & {$[4]$} \\
\hline
\end{tabular}

*L-(7-hydroxycoumarin-4-yl) ethylglyl,

\$Empty boxes in table indicates residues same as in wild type tyrosyl synthetase

Similarly, the introduction of Amber mutations in EmGFP at 39 and 214 positions were carried out by above mentioned procedure by using primers 13-16.

Figure S1: Plasmid map of pEVOL-uaa (A) and pEVOL-3IYRS-EmGFP (B)
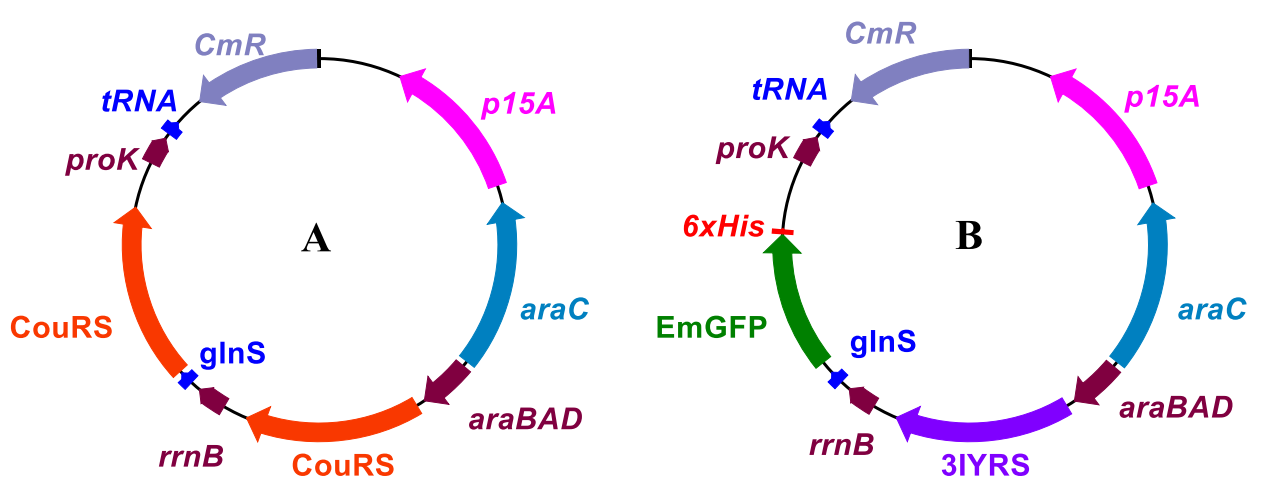

pEVOL-3IYRS-EmGFP (WT), pEVOL-3IYRS-EmGFP-1TAG in combination with 3-Chloro, 3-Bromo, and 3-iodo-L-tyrosine) and pEVOL-3IYRS-EmGFP-2TAG with 3-iodo-L-tyrosine variants (listed in Table S3) were expressed and purified using E. coli strain C321 $\triangle$ A.exp (Church Lab, Addgene plasmid \# 49018).[7a]

Table S3: List of mutations in combination with 3-halo-L-tyrosines.

\begin{tabular}{|c|l|l|l|l|}
\hline SI. No & \multicolumn{1}{|c|}{ Plasmid } & $\begin{array}{c}\text { TAG position } \\
\text { in EmGFP }\end{array}$ & \multicolumn{1}{|c|}{ 3-Halo-L-tyrosine } & \multicolumn{1}{|c|}{ Protein label } \\
\hline 1 & pEVOL-3IYRS-EmGFP & --- & L-tyrosine* & WT \\
\hline 2 & pEVOL-3IYRS-EmGFP & 39 & 3-chloro-L-tyrosine & EmGFP-1TAG-3CIY \\
\hline 3 & pEVOL-3IYRS-EmGFP & 39 & 3-bromo-L-tyrosine & EmGFP-1TAG-3BrY \\
\hline 4 & pEVOL-3IYRS-EmGFP & 39 & 3-iodo-L-tyrosine & EmGFP-1TAG-3IY \\
\hline 5 & pEVOL-3IYRS-EmGFP & $39 \& 214$ & 3-iodo-L-tyrosine & EmGFP-2TAG-3IY \\
\hline
\end{tabular}

*endogenous L-tyrosine

E. coli C321. $\triangle$ A.exp cells were transformed with pEVOL-3IYRS-EmGFP or pEVOL-3IYRSEmGFP1TAG or pEVOL-3IYRS-EmGFP-2TAG, individual colonies were inoculated in L.B broth supplemented with chloramphenicol $(34 \mu \mathrm{g} / \mathrm{mL})$ and grown at $37^{\circ} \mathrm{C}$ for $12-14 \mathrm{~h}$ with a speed of 220 $\mathrm{rpm}$ in orbital shaking incubator. Saturated cultures were diluted to a $0.08 \mathrm{OD}_{600}$ with fresh L.B 
supplemented with chloramphenicol $(34 \mu \mathrm{g} / \mathrm{mL})$, IPTG $(1.0 \mathrm{mM})$ and L-arabinose $(0.2 \%)$. To express the variants having 3-iodo-L-tyrosine, 3-bromo-L-tyrosine and 3-chloro-L-tyrosine at 39-position of EmGFP-1TAG and only 3-iodo-L-tyrosine in 39- and 214-position of EmGFP-2TAG, the corresponding amino acids 3-iodo-L-tyrosine, 3-bromo-L-tyrosine and 3-chloro-L-tyrosine were supplemented in L.B to a final concentration of $1.0 \mathrm{mM}$ allowed the cultures to grow for $24 \mathrm{~h}$ at $37^{\circ} \mathrm{C}$ shaking with a speed of $220 \mathrm{rpm} .{ }^{[7 \mathrm{~b}]}$

Cells were pelleted down and suspended in Lysis buffer and sonicated to lyse the cells. The cell debris was removed by centrifugation at $21,000 \mathrm{~g}$ for $1.0 \mathrm{~h}$, further the lysates were subjected to ultracentrifugation at $1,00,000 \mathrm{~g}$ for additional $1.0 \mathrm{~h}$. The clear supernatant was loaded into Ni-NTA Columns (HisTrap ${ }^{T M}$ HP Columns form G.E. Healthcare were used with Bio-Rad Due flow FPLC system). The C-terminal 6xHis-tagged proteins were purified by Ni-NTA affinity chromatography protocol. Briefly, $40 \mathrm{~mL}$ lysate was loaded into Ni-NTA column and washed with 15 column volumes of wash buffer and eluted with elution buffer by concentration gradient of imidazole (50 mM to $400 \mathrm{mM}$ in $100 \mathrm{~mL}$ elution volume). Imidazole was removed and proteins were concentrated by using Amicon Ultra centrifugal filters having $10 \mathrm{kDa}$ MWCO. Finally, the proteins were stored in $50 \mathrm{mM}$ sodium phosphate buffer with $10 \%$ glycerol at $-80{ }^{\circ} \mathrm{C}$. The purity of proteins was analyzed by $12 \%$ SDSPAGE (Fig 1C and 4C). Bradford assays were performed to determine the protein concentrations by comparing with a set of bovine serum albumin (BSA) standards. The incorporation of unnatural amino acids (3-iodo-L-tyrosine, 3-bromo-L-tyrosine and 3-chloro-L-tyrosine) was confirmed by mass spectrometry (Table S4 and Figure S6-S10). All the proteins showed expected mass.

Table S4: Table showing the mass list of expected, observed mass of proteins.

\begin{tabular}{|c|c|c|c|}
\hline Protein & Expected mass (Da) & $\begin{array}{c}\text { Observed mass } \\
(\mathbf{D a})\end{array}$ & $\begin{array}{c}\text { Difference } \\
(\mathbf{D a})\end{array}$ \\
\hline WT & 27943.52 & 27943.18 (Fig. S6) & -0.34 \\
\hline EmGFP-1TAG-3CIY & 27979.02 & 27977.46 (Fig. S7) & -1.56 \\
\hline EmGFP-1TAG-3BrY & 28023.42 & 28022.47 (Fig. S8) & -0.95 \\
\hline EmGFP-1TAG-3IY & 28070.42 & 28069.32 (Fig. S9) & -1.1 \\
\hline EmGFP-2TAG-3IY & 28231.31 & 28233.00 (Fig. S10) & +1.69 \\
\hline
\end{tabular}

\subsection{Mass spectrometry}

Mass spectra were recorded using LC-ESI-QTOF (maXis Impact, Bruker Daltonics, Germany) mass spectrometer at the Proteomics facility, Molecular Biophysics Unit, Indian Institute of Science.

\subsection{UV-Visible and Fluorescence Spectroscopy}

The UV-Visible absorption spectra were recorded by using a Shimadzu UV-2600, UV-Vis spectrophotometer, and Fluorescence spectra were recorded by using FluoroMax-4, HORIBA JOBIN YVON, spectrofluorimeter. The UV-Vis and fluorescence studies were carried out in $50 \mathrm{mM}$ sodium 
phosphate buffer at a pH of 7.5 using the protein concentrations $25 \mu \mathrm{M}$ and $5 \mu \mathrm{M}$, respectively. The spectra were plotted using OriginLab 8.0 and are normalized (Figure 2A).

\subsection{Circular Dichroism}

The proteins were diluted in $50 \mathrm{mM}$ phosphate buffer $(\mathrm{pH}$ 7.5) to the final concentration of $10 \mu \mathrm{M}$. The CD spectra were recorded in the 190-230 nm range using a JASCO J-715 model spectropolarimeter and scanned 3 times with data patch of $0.5 \mathrm{~nm}$ bandwidth and $100 \mathrm{~nm} / \mathrm{sec}$ speed. All the spectra are reported after a baseline correction with $50 \mathrm{mM}$ phosphate buffer $(\mathrm{pH} 7.5)$.

\subsection{Cell lines and culture condition}

HepG2 hepatocellular carcinoma (HB8065) was obtained from ATCC, Washington DC, USA. The cells were grown in MEM supplemented with $2.2 \mathrm{~g} / \mathrm{L}$ sodium bicarbonate, $10 \%$ supplemental FBS, penicillin $\mathrm{G}$ (100 unites $/ \mathrm{mL}$ ) streptomycin $(100 \mathrm{mg} / \mathrm{mL})$. The cells were cultured till $80-90 \%$ confluence and further sub-cultured in different sized cell culture dishes/plates depending on the type of experiment in a humidified incubator at $37{ }^{\circ} \mathrm{C}$ with $5 \% \mathrm{CO}_{2}$. For fluorescence reader assays, the cells were cultured on black walled 96 -well plates with clear film bottom.

\subsection{Cell viability assay with MTT}

The viability of the cells was determined using a 3-(4,5-dimethylthiazol-2-yl)-2,5-diphenyl tetrazolium bromide (MTT) colorimetric assay as described previously. ${ }^{[8]}$ The cells were plated on 96-well microtiter cell culture plates at 20,000 cells per well for $24 \mathrm{~h}$ before they were incubated for $90 \mathrm{~min}$ with various concentrations of EmGFP variants. After the indicated treatment period, the cells were incubated for $3 \mathrm{~h}$ at $37^{\circ} \mathrm{C}$ in a culture medium containing $10 \mu \mathrm{mol} \mathrm{L}-1 \mathrm{MTT}$ in phosphate-buffered saline (PBS). The blue MTT formazan precipitate was then dissolved in $100 \mu \mathrm{L}$ of DMSO, and the absorbance was measured at $570 \mathrm{~nm}$ with a multi-well plate reader. The cell viability was expressed as the percentage of the absorption values in the treated cells relative to the non-treated (control) cells. The data are presented as the means \pm the standard error of the triplicated cultures.

\subsection{Cell treatment conditions}

For the low temperature studies, the cells were first incubated at $4{ }^{\circ} \mathrm{C}$ for $1 \mathrm{~h}$ and then incubated with EmGFP proteins for $1 \mathrm{~h}$ at $4{ }^{\circ} \mathrm{C}$ and cold PBS containing Heparin (1 mg/mL) and subsequently the cells were analysed by microplate reader (or) confocal imaging. For the ATP depletion studies, HepG2 cells were incubated with ATP depletion medium (glucose-free DMEM with $10 \mathrm{mM}$ sodium azide and $6 \mathrm{mM}$ 2-deoxy-D-glucose) containing 10\% fetal calf serum for $1.5 \mathrm{~h}$, followed by incubation with different EmGFP proteins1 $\mathrm{h}$ in serum-free ATP depletion medium. For the studies with endocytosis inhibitors, the HepG2 cells were first pre-treated with chlorpromazine (CPZ, C8138 Sigma, $10 \mu \mathrm{M} / \mathrm{mL}$ ) or methyl- $\beta$-cyclodextrin-MßCD (C4555, Sigma, $10 \mathrm{mM}$ ) or genistein (GST, G6649 
Sigma, $200 \mu \mathrm{M}$ ) in normal culture medium for $30 \mathrm{~min}$ at $37^{\circ} \mathrm{C}$. Subsequently, the cells were further incubated with EmGFP proteins for $90 \mathrm{~min}$ and were analyzed by microplate reader (or) confocal imaging.

\subsection{Intracellular fluorescence intensity assay}

After seeding the cells in to 96 -well cell culture grade microtiter plates at 20,000 cells/well and culturing for $24 \mathrm{~h}$, the cells were treated with proteins and inhibitors for various time points according to the experimental conditions, then washed 3 times with cold PBS containing Heparin $(1 \mathrm{mg} / \mathrm{mL})$. After washing, the MEM medium was added and the fluorescence intensity in the cells was measured by GloMax Microplate Reader (Promega).

\subsection{Confocal microscopy}

The cells were cultured on glass coverslips in 12 -well culture plates $\left(0.2 \times 10^{6}\right.$ per well). They were allowed to adhere and proliferate for $24 \mathrm{~h}$. Cells were then incubated with EmGFP proteins or inhibitors at different time points depending on the experimental condition. After the treatment, the cells were washed with cold PBS containing Heparin $(1 \mathrm{mg} / \mathrm{mL})$ and fixed with $4 \%$ PFA (paraformaldehyde) followed by wash with PBS buffer. Finally, the cover slips containing fixed cells were mounted on microscopic slides using fluoromount (F4680, Sigma). Images were captured with Zeiss LSM880 (Airyscan) and Leica TCS SP8 confocal microscopy and images were further analysed and extracted using Zen v2.3 (blue edition) and LAS X (Leica) software.

\subsection{FACS Analysis}

Cells were seeded in 6-well plates $\left(1 \times 10^{5}\right.$ cells/well) and allowed to adhere and proliferate for $24 \mathrm{~h}$. Then, the cells were treated with EmGFP proteins or inhibitors at different time points depending on the experimental conditions. After the treatment, the cells were washed with PBS and treated with $0.5 \%$ trypsin/EDTA solution. The detached cells were pelleted down by centrifugation and cells were re-suspended in MEM. Then, the fluorescence intensity was measured using FACSCelesta flow cytometer (BD Biosciences, San Jose, CA) using CellQuest (BD Biosciences) acquisition software. Data analysis was performed with FSC Express 6.0 Flow Cytometry Analysis software. 


\section{Results}

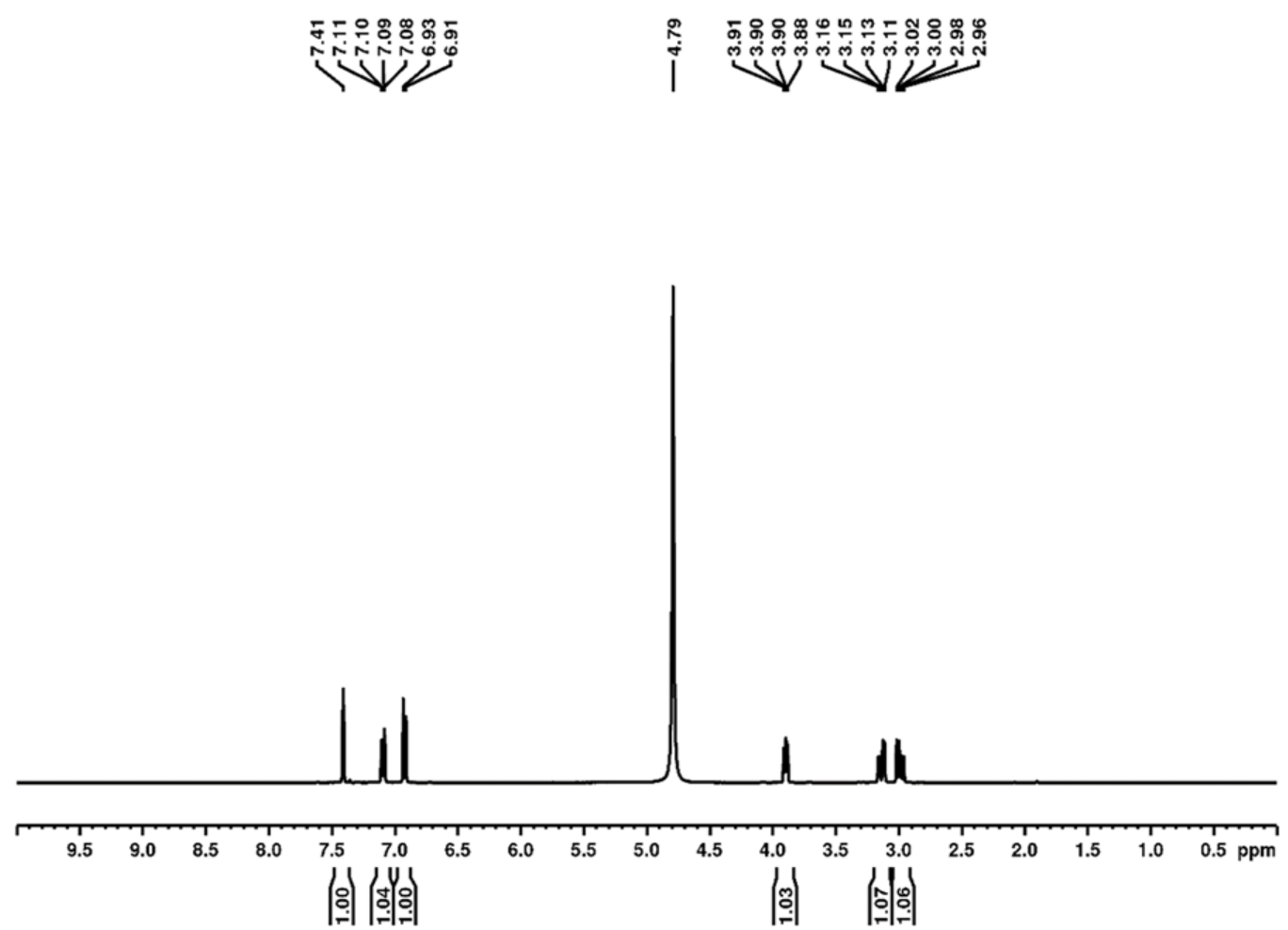

Figure S2: ${ }^{1} \mathrm{H}$ NMR spectrum $\left(\mathrm{D}_{2} \mathrm{O}, 400 \mathrm{MHz}\right)$ of 3-bromo- L-tyrosine.

إj

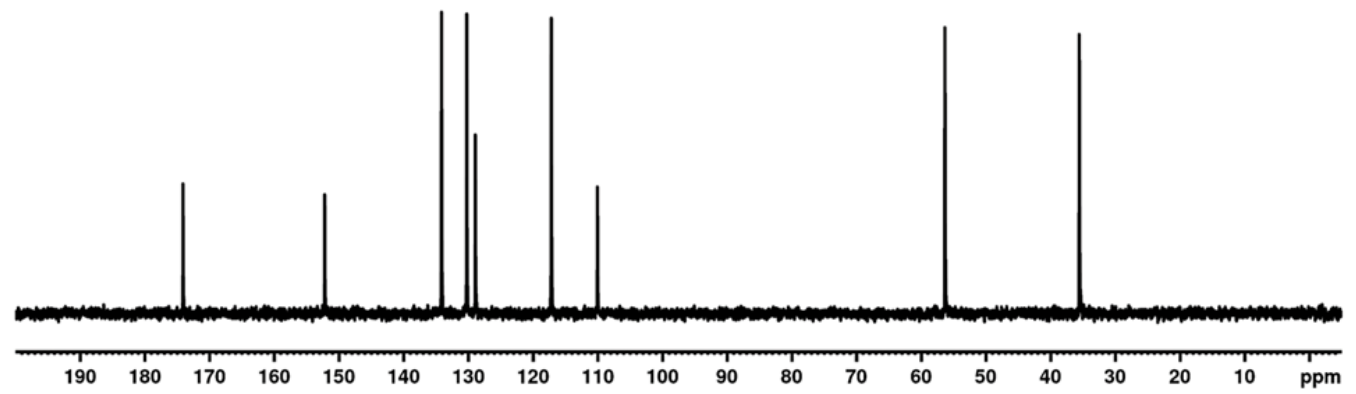

Figure S3: ${ }^{13} \mathrm{C}$ NMR spectrum $\left(\mathrm{D}_{2} \mathrm{O}, 100.59 \mathrm{MHz}\right)$ of 3-bromo-L-tyrosine. 


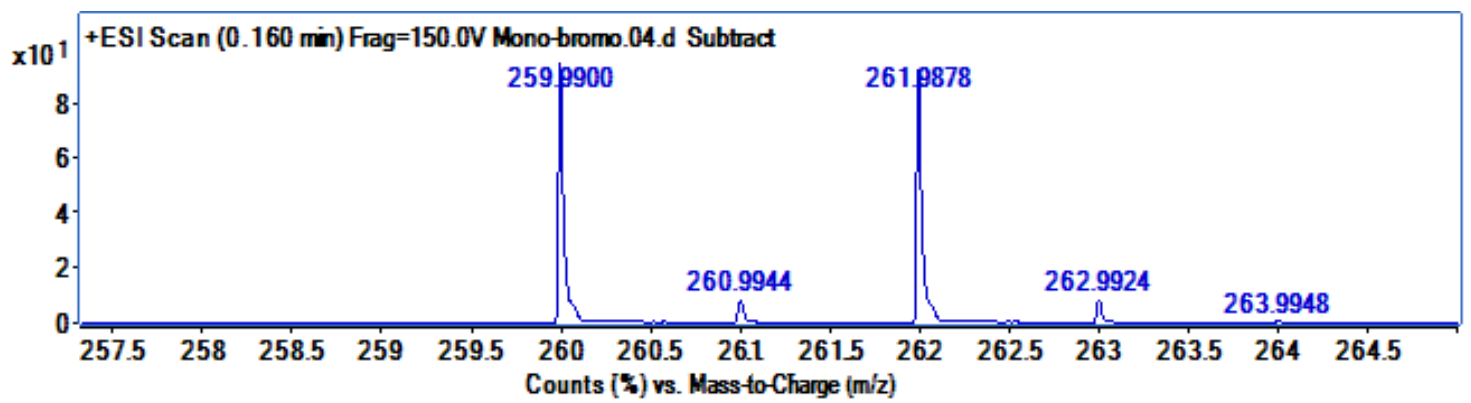

Figure S4. ESI- MS of 3-bromo-L-tyrosine.

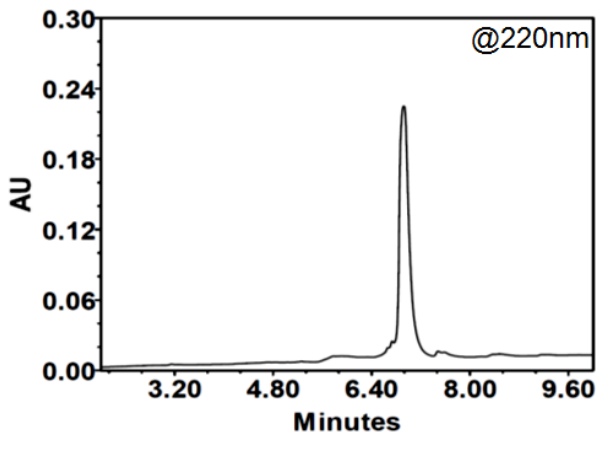

(A)

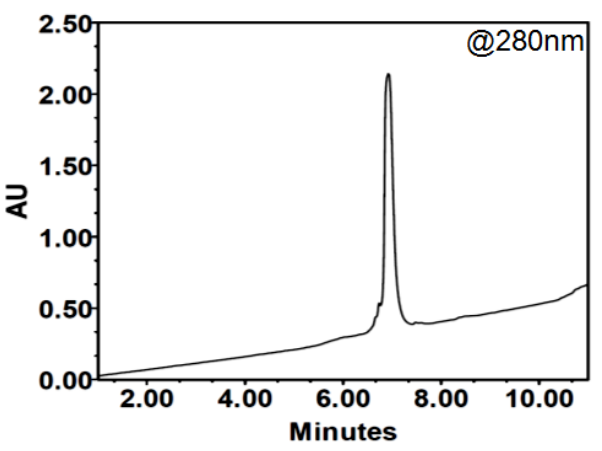

(B)

Figure S5: HPLC chromatogram of ppTG21 peptide at $220 \mathrm{~nm}$ (A) and $280 \mathrm{~nm}$ (B). 
(A)

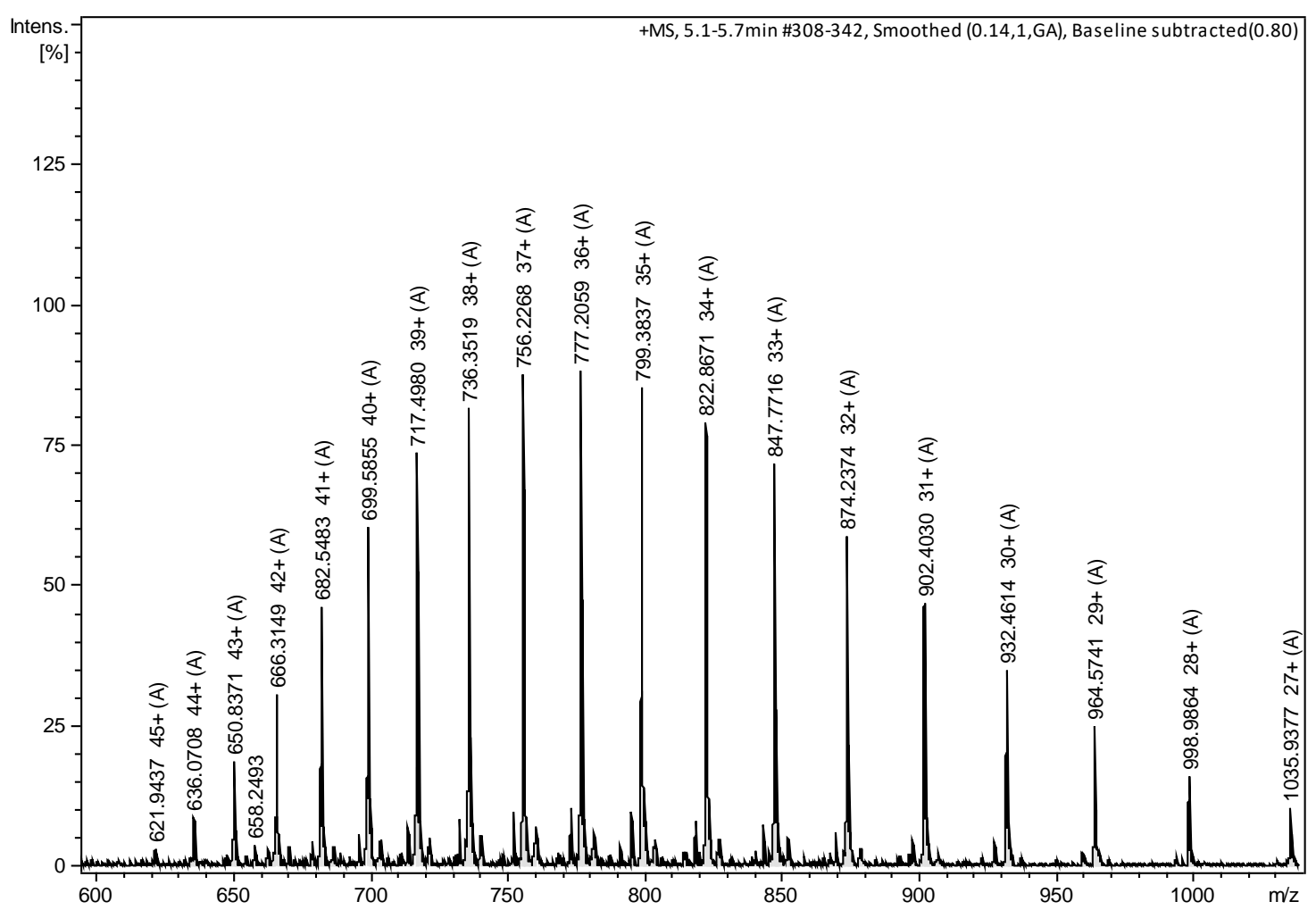

(B)

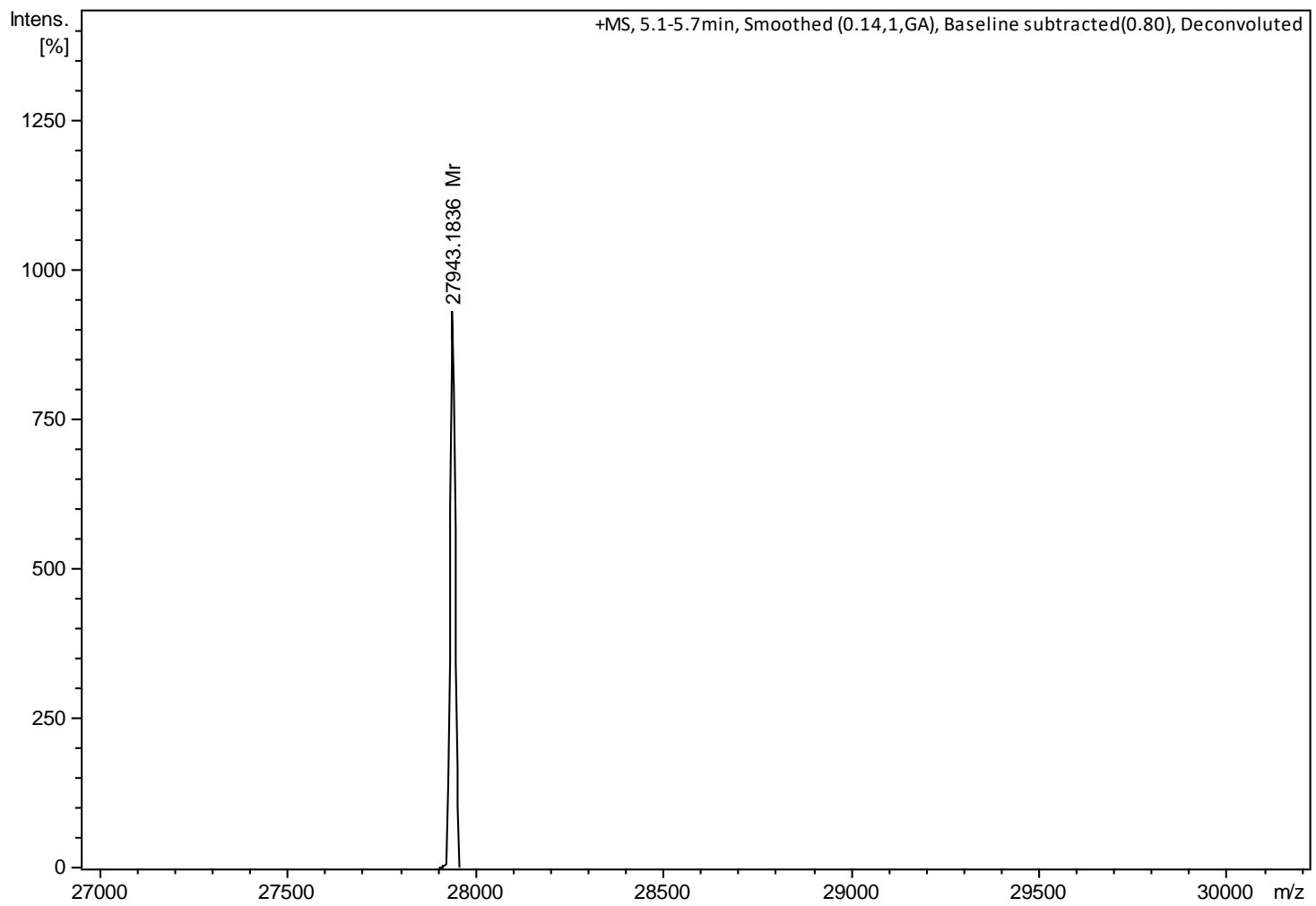

Figure S6. Mass Spectrum of EmGFP-WT showing the charged envelope (A) and deconvoluted spectrum (B). 
(A)

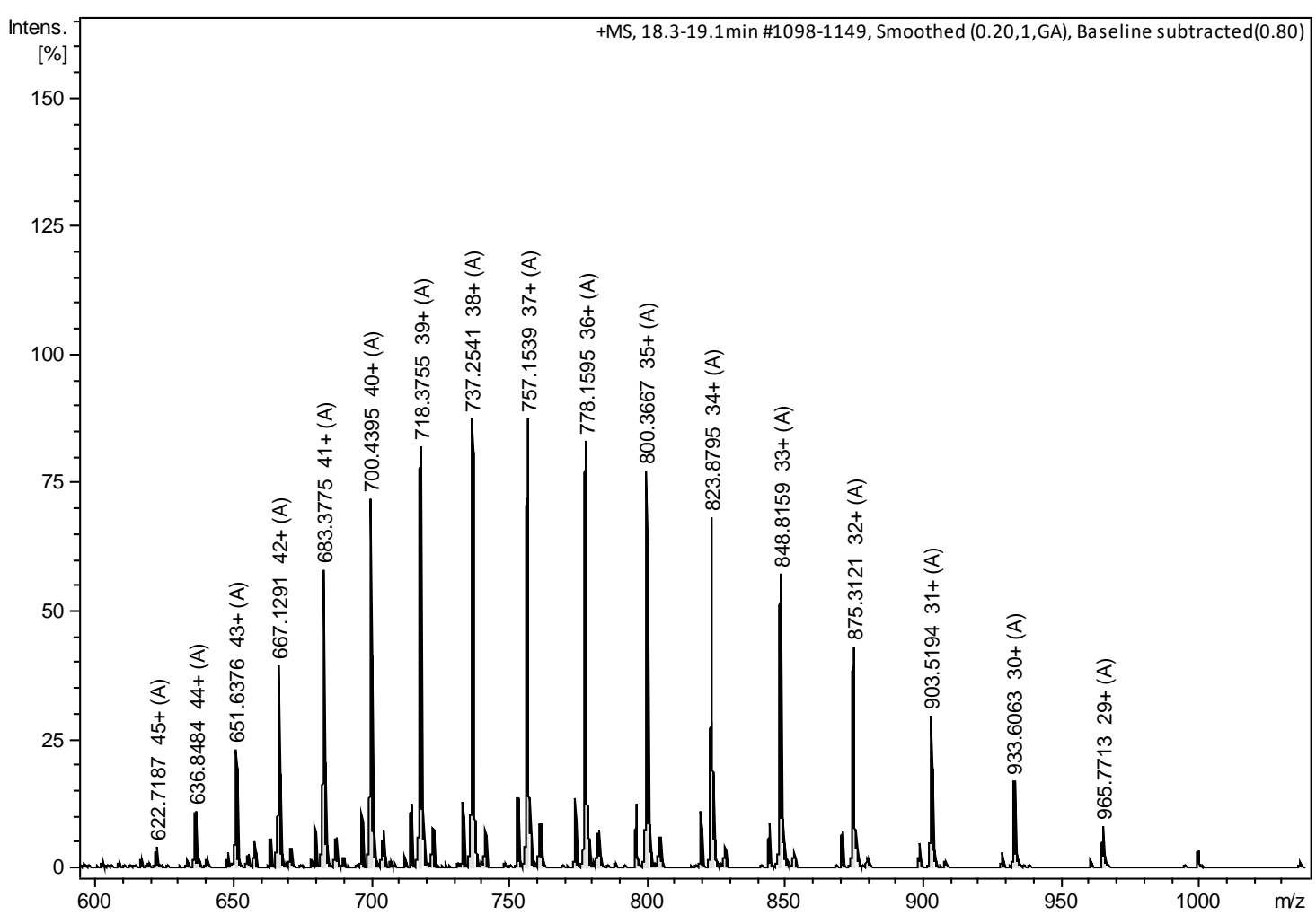

(B)

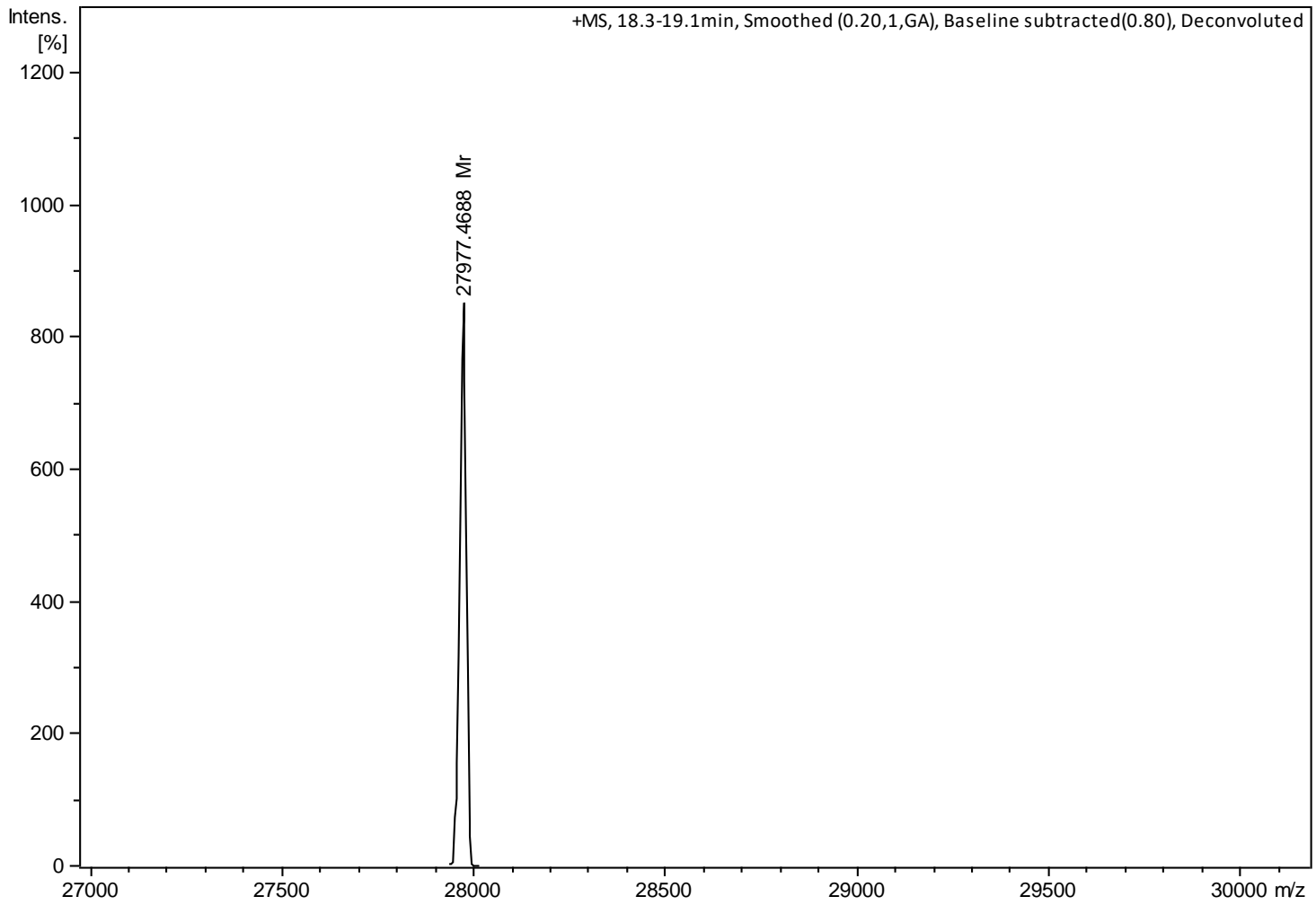

Figure S7. Mass Spectrum of EmGFP-1TAG-3CIY showing the multiply charged envelope (A) and deconvoluted spectrum (B). 
(A)

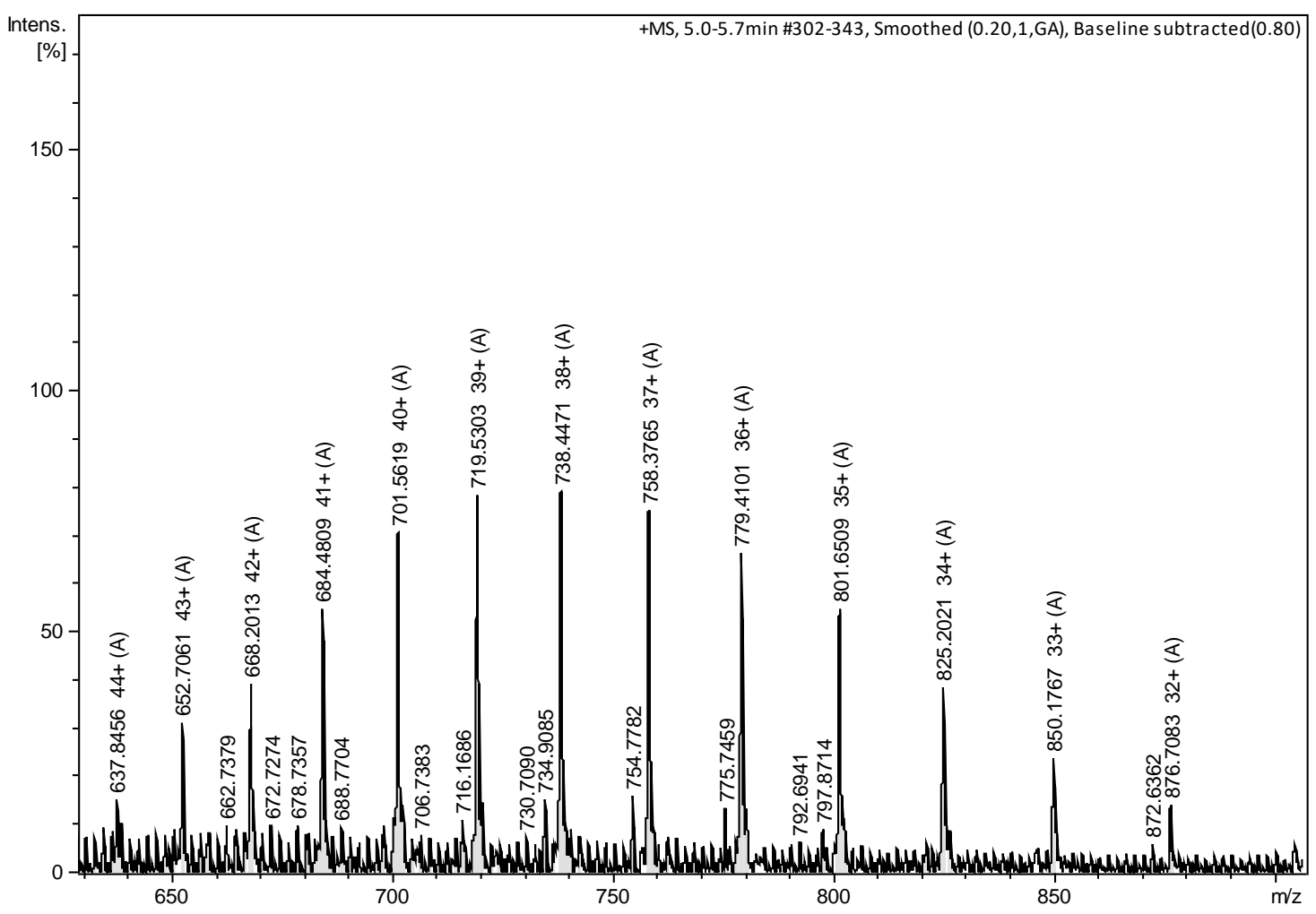

(B)

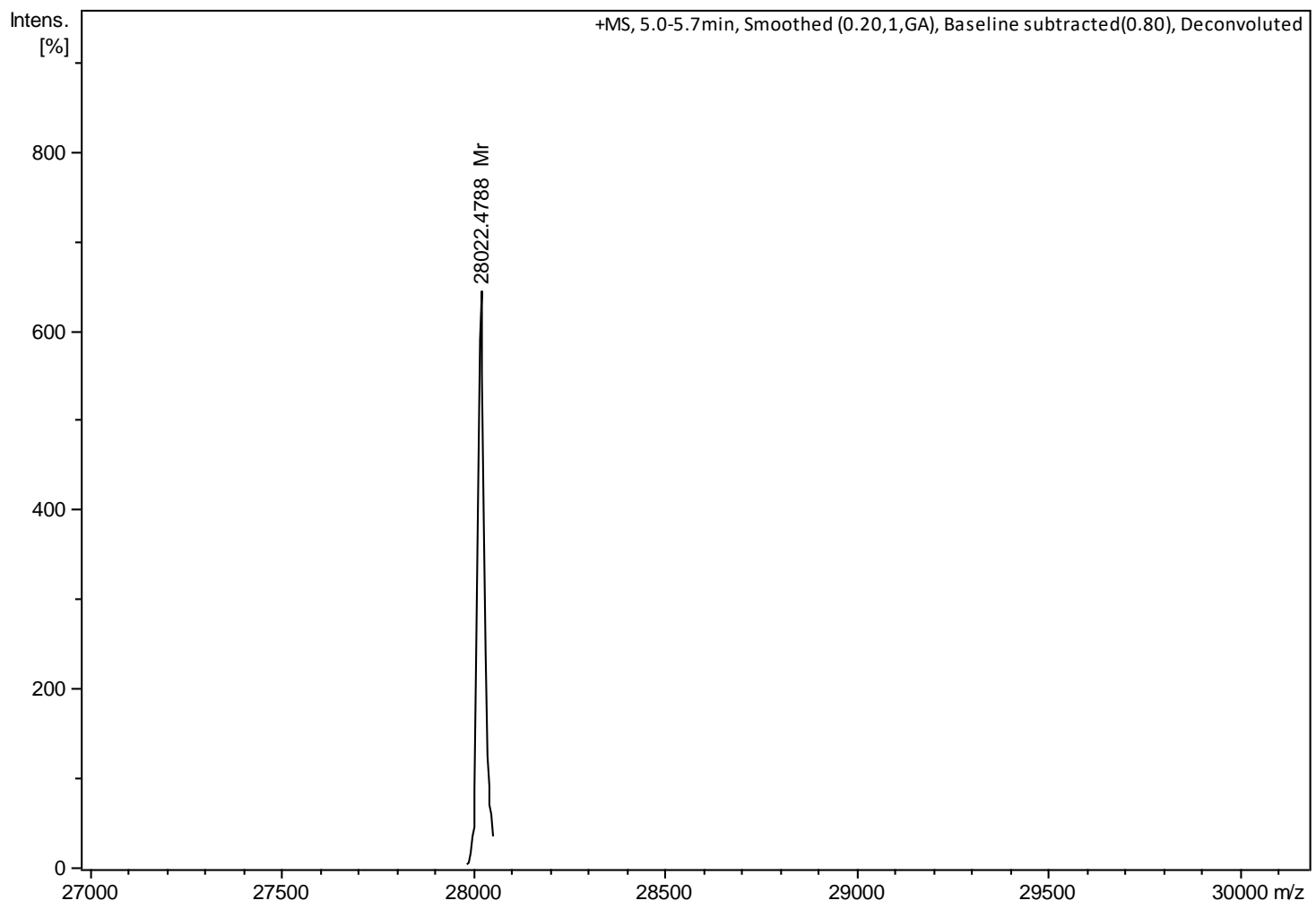

Figure S8. Mass Spectrum of EmGFP-1TAG-3BrY showing the multiply charged envelope (A) and deconvoluted spectrum (B). 
(A)

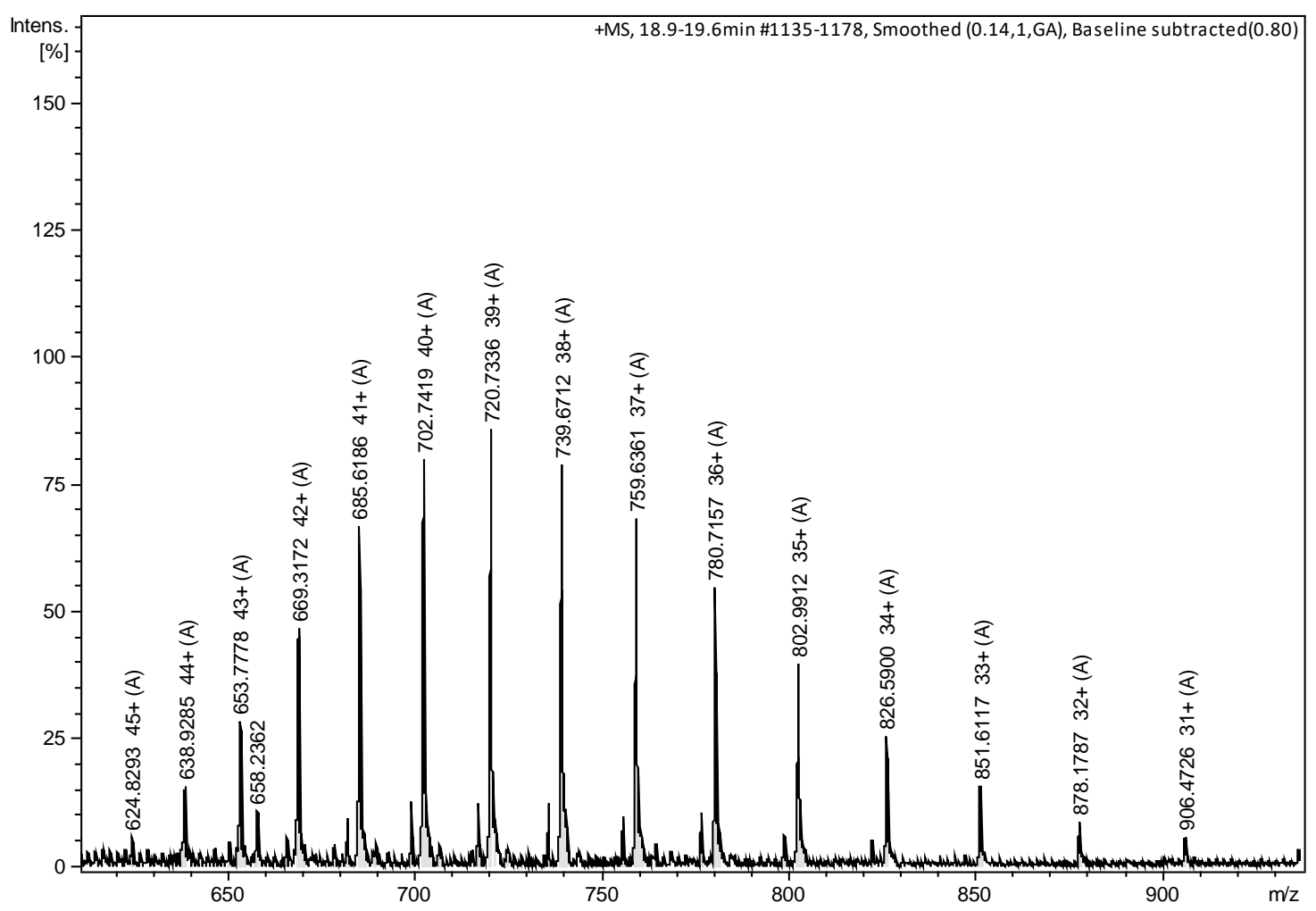

(B)

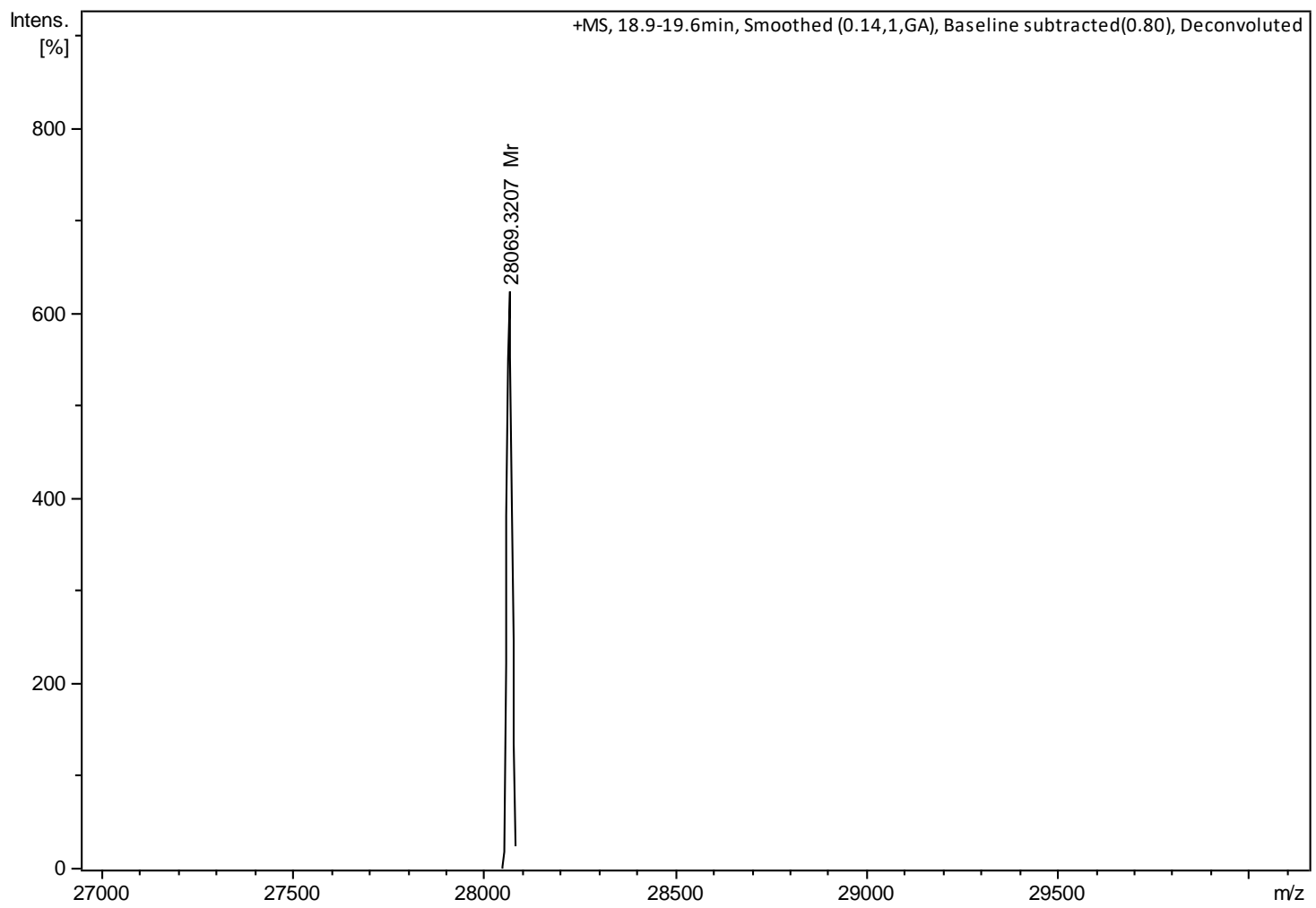

Figure S9. Mass Spectrum of EmGFP-1TAG-3IY showing charged envelope (A) and deconvoluted spectrum (B). 
(A)

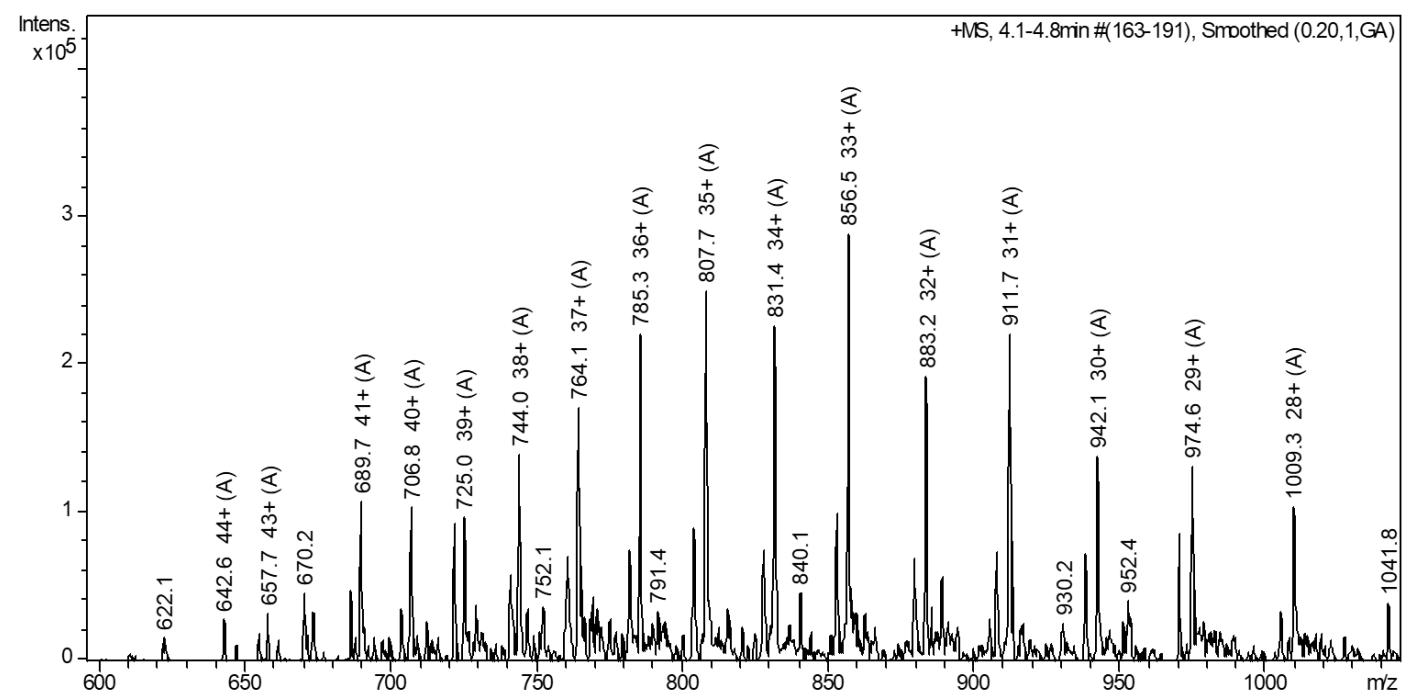

(B)

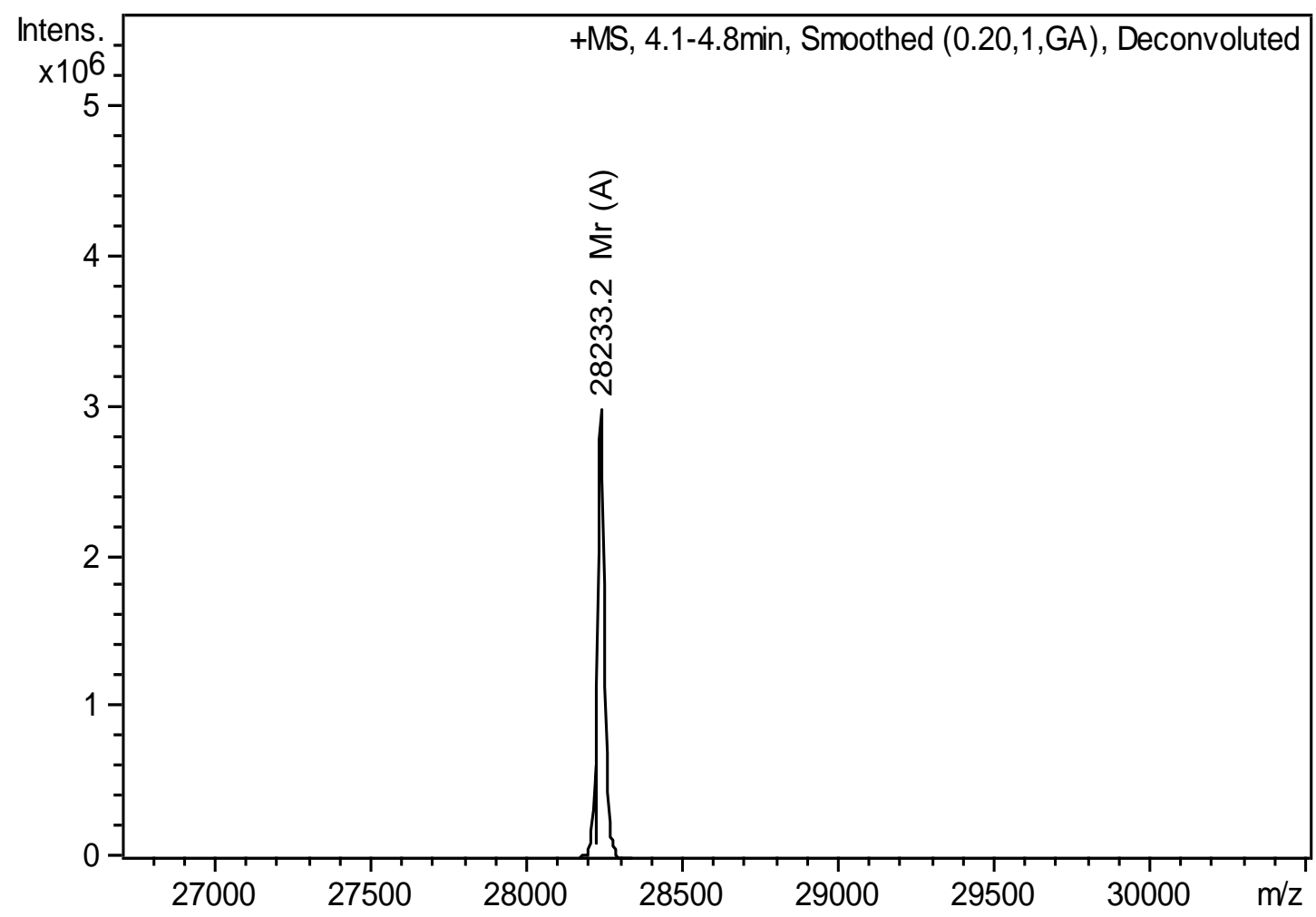

Figure S10: Mass Spectrum of EmGFP-2TAG-3IY showing charged envelope (A) and deconvoluted spectrum (B). 


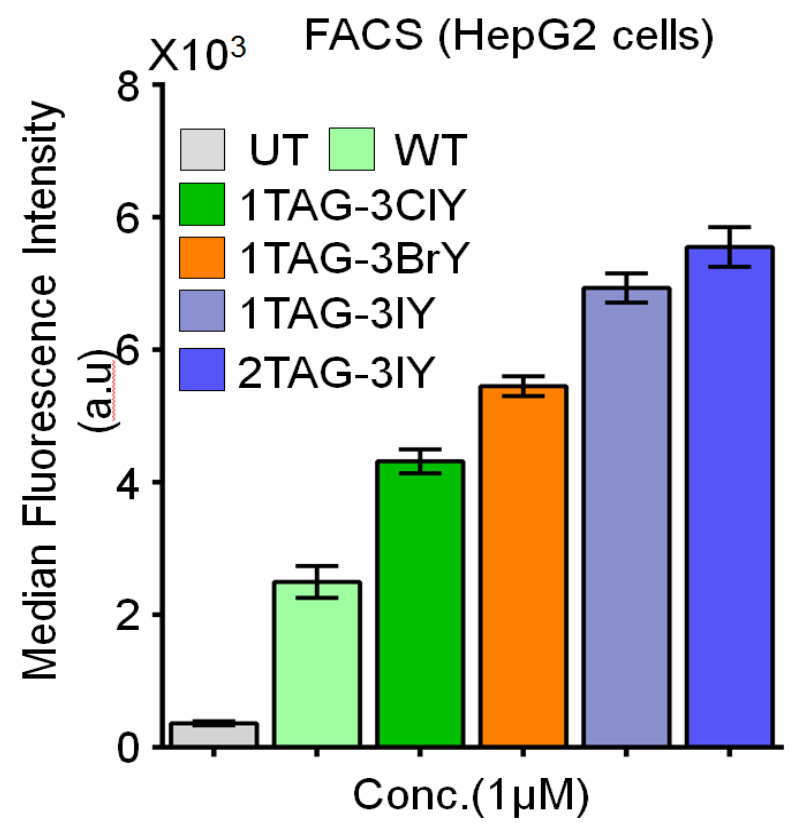

Figure S11: The fluorescence intensity measured by FACS after $90 \mathrm{~min}$ of treatment of HepG2 cells with $1 \mu \mathrm{M}$ halo-EmGFP. 

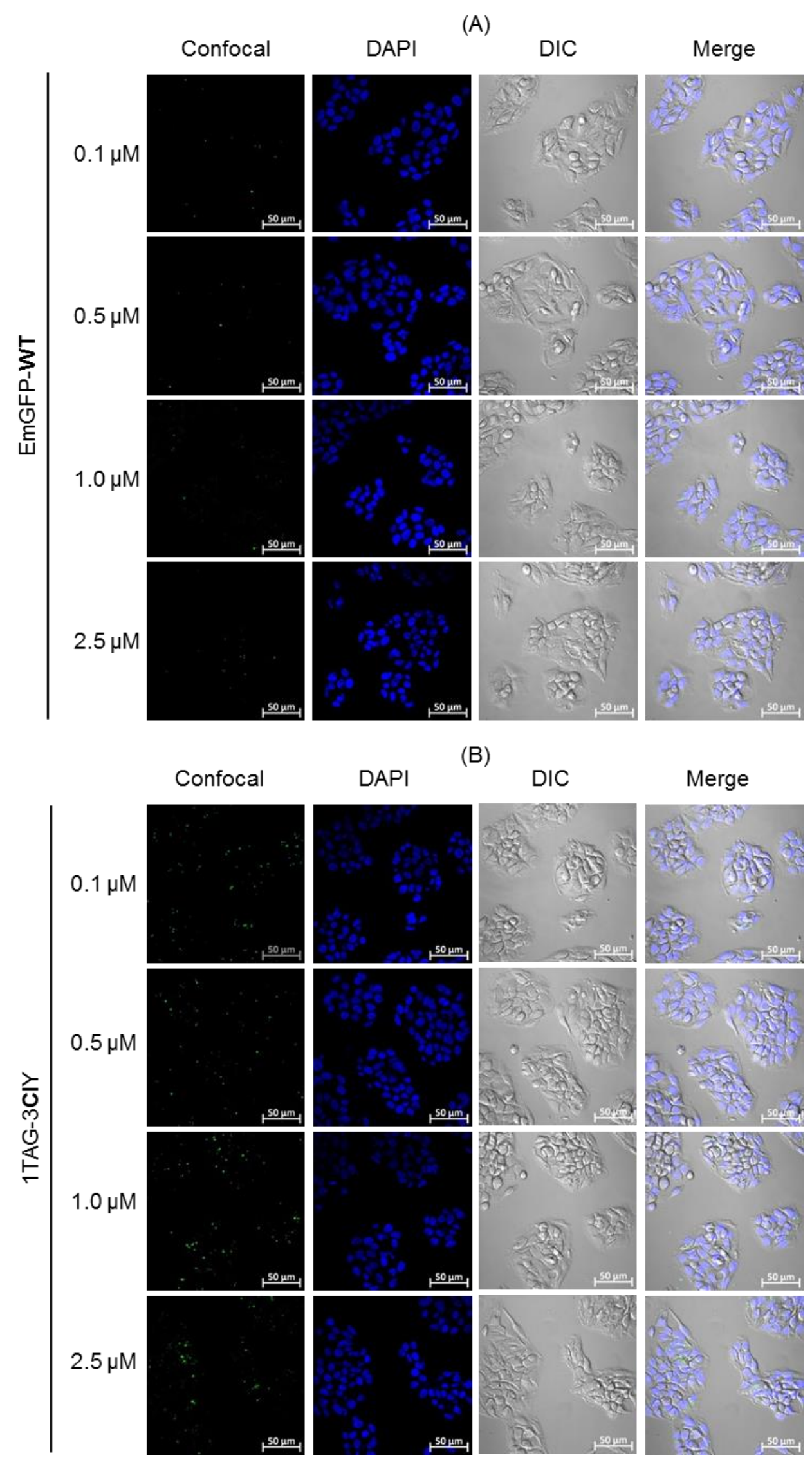

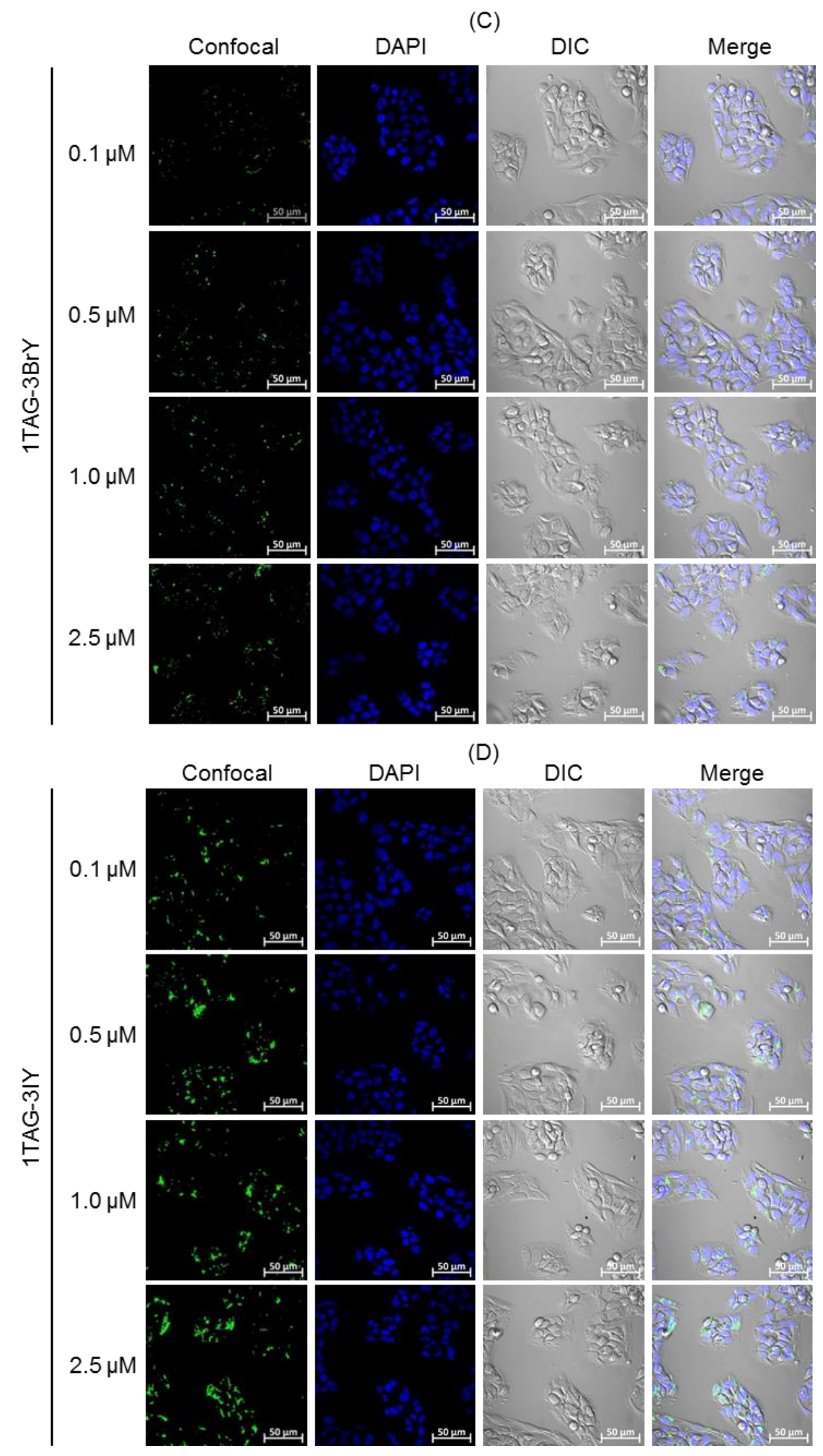

Figure S12: Confocal images of HepG2 cells treated with various concentrations of halo-EmGFP (1TAG) for $90 \mathrm{~min}$. 
(A)

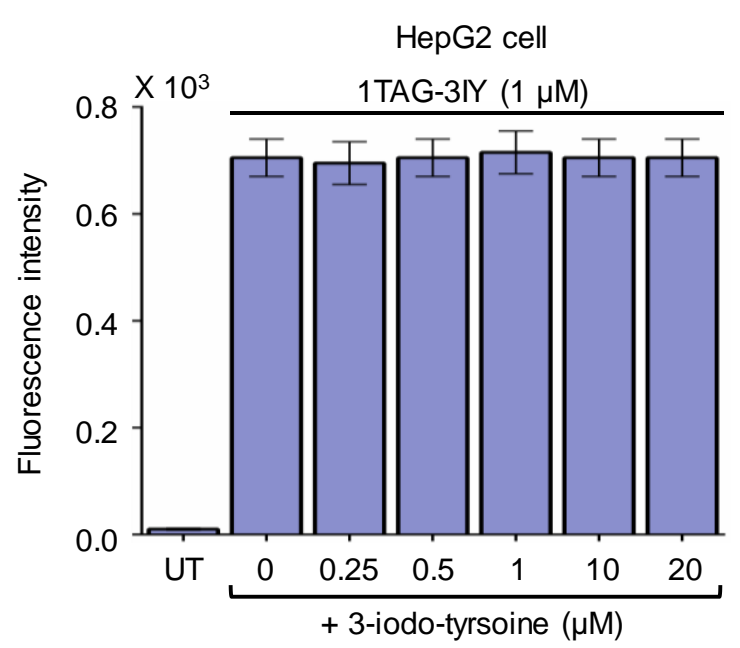

(B)

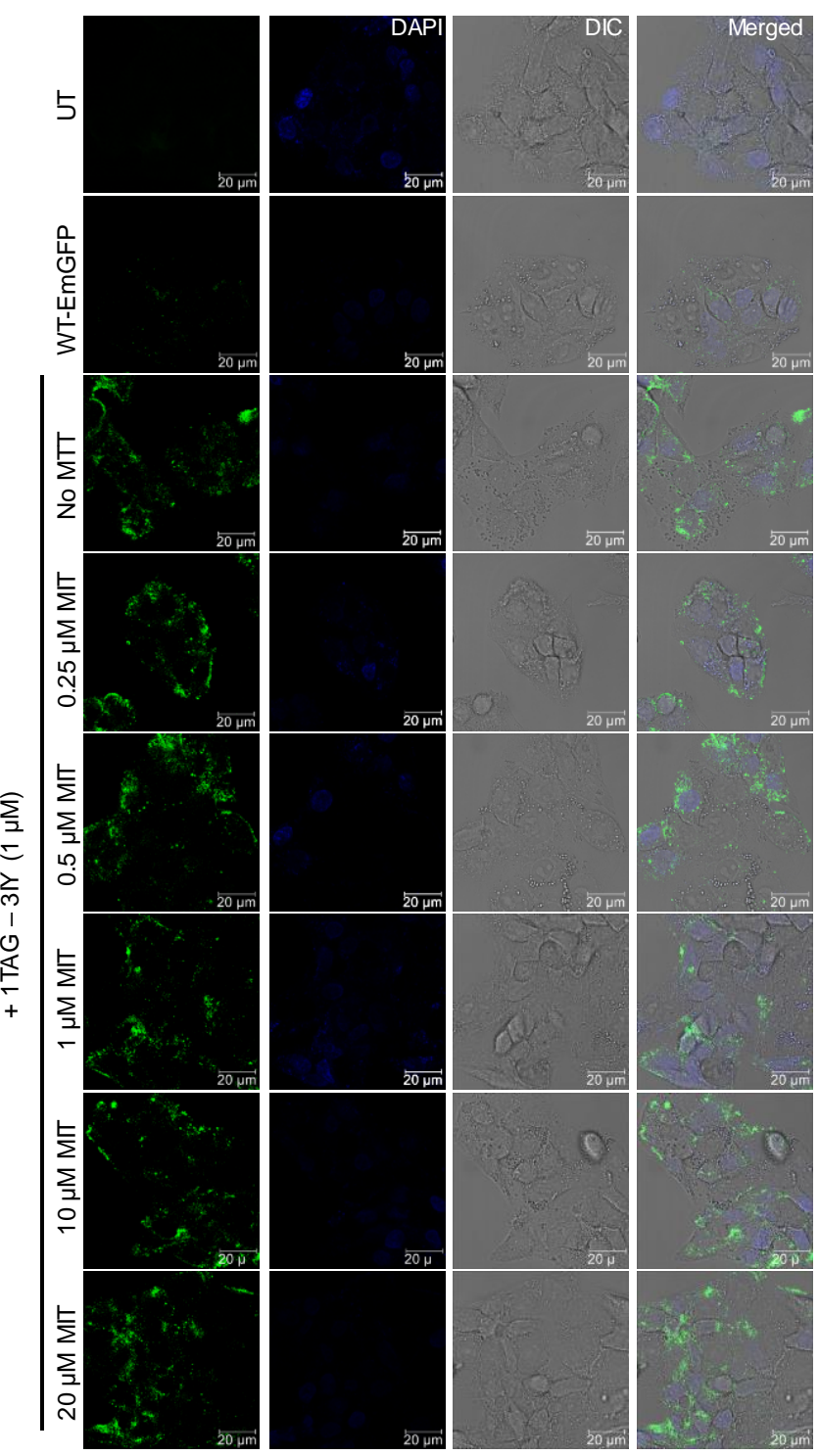

Figure S13: The fluorescence measured by a plate reader after 90 min treatment of HepG2 cells with $1 \mu \mathrm{M}$ of $1 \mathrm{TAG}$-3IY EmGFP at $37{ }^{\circ} \mathrm{C}$ after co-treatment with 3-iodo-L-tyrosine (MIT) (A) and the corresponding confocal images $(B)$. 

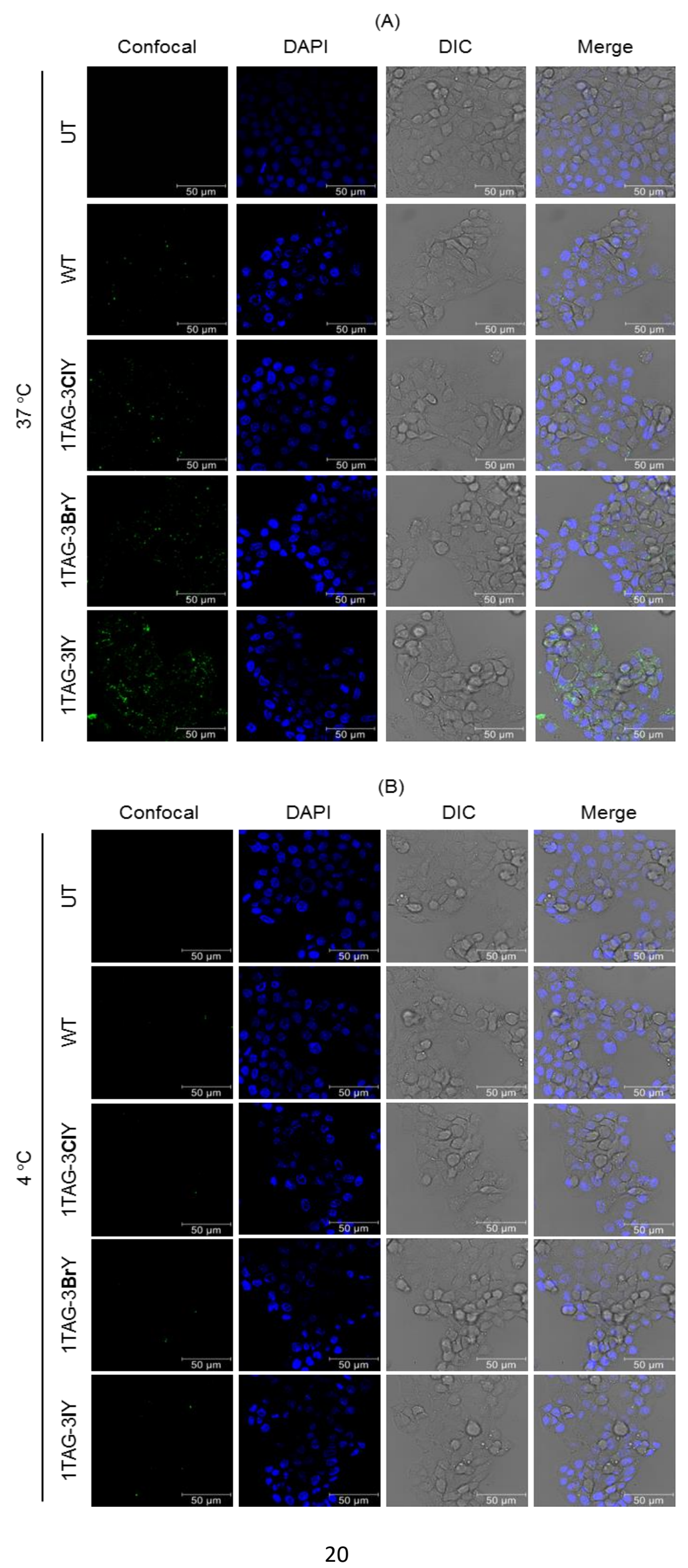

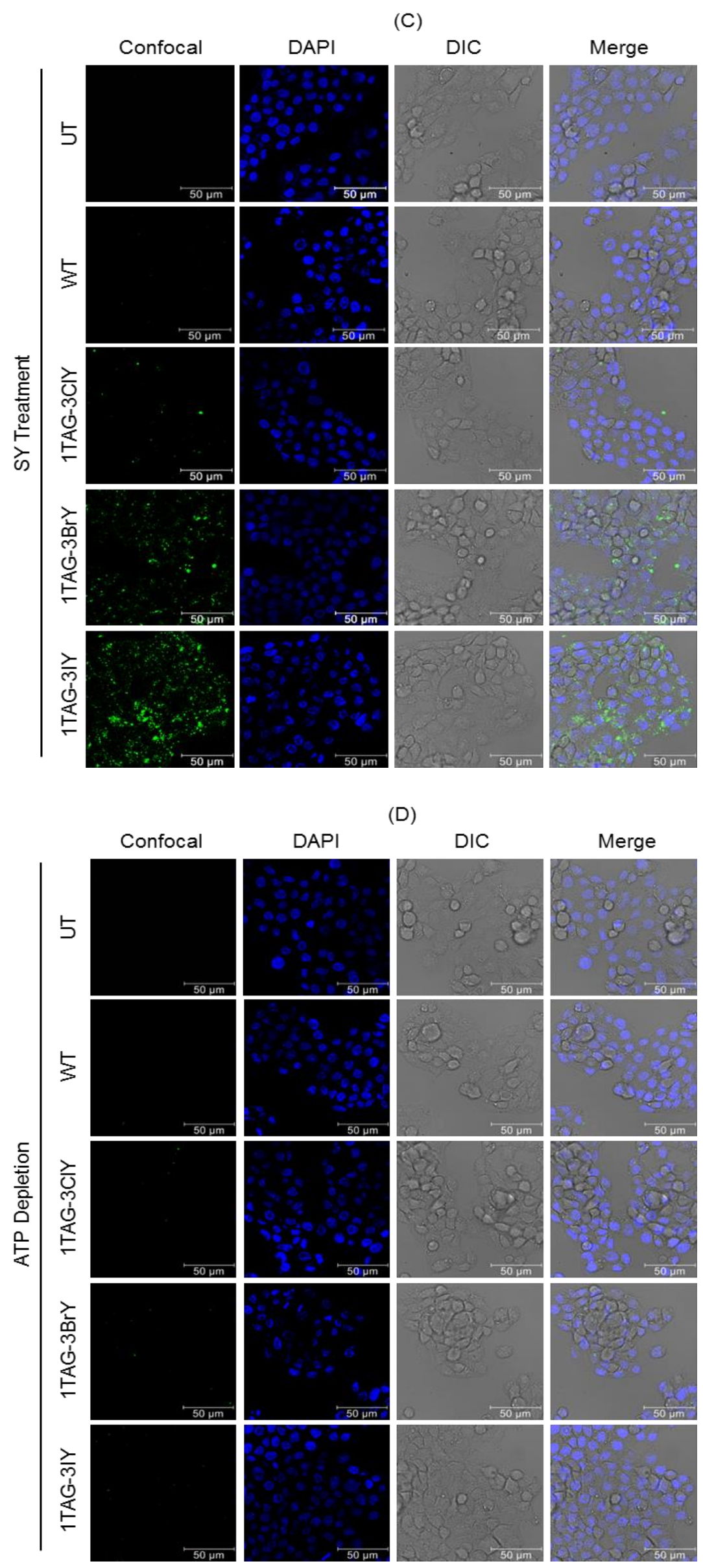

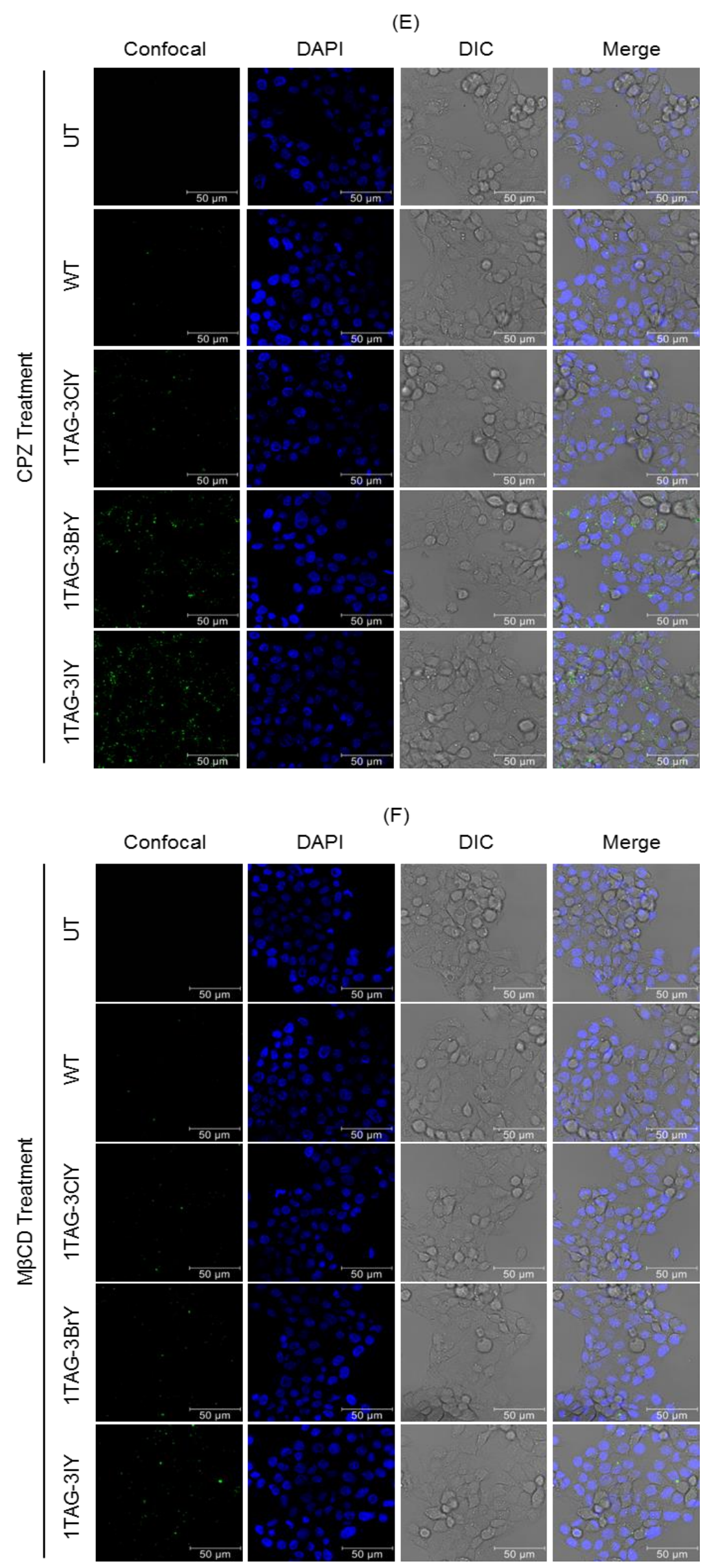


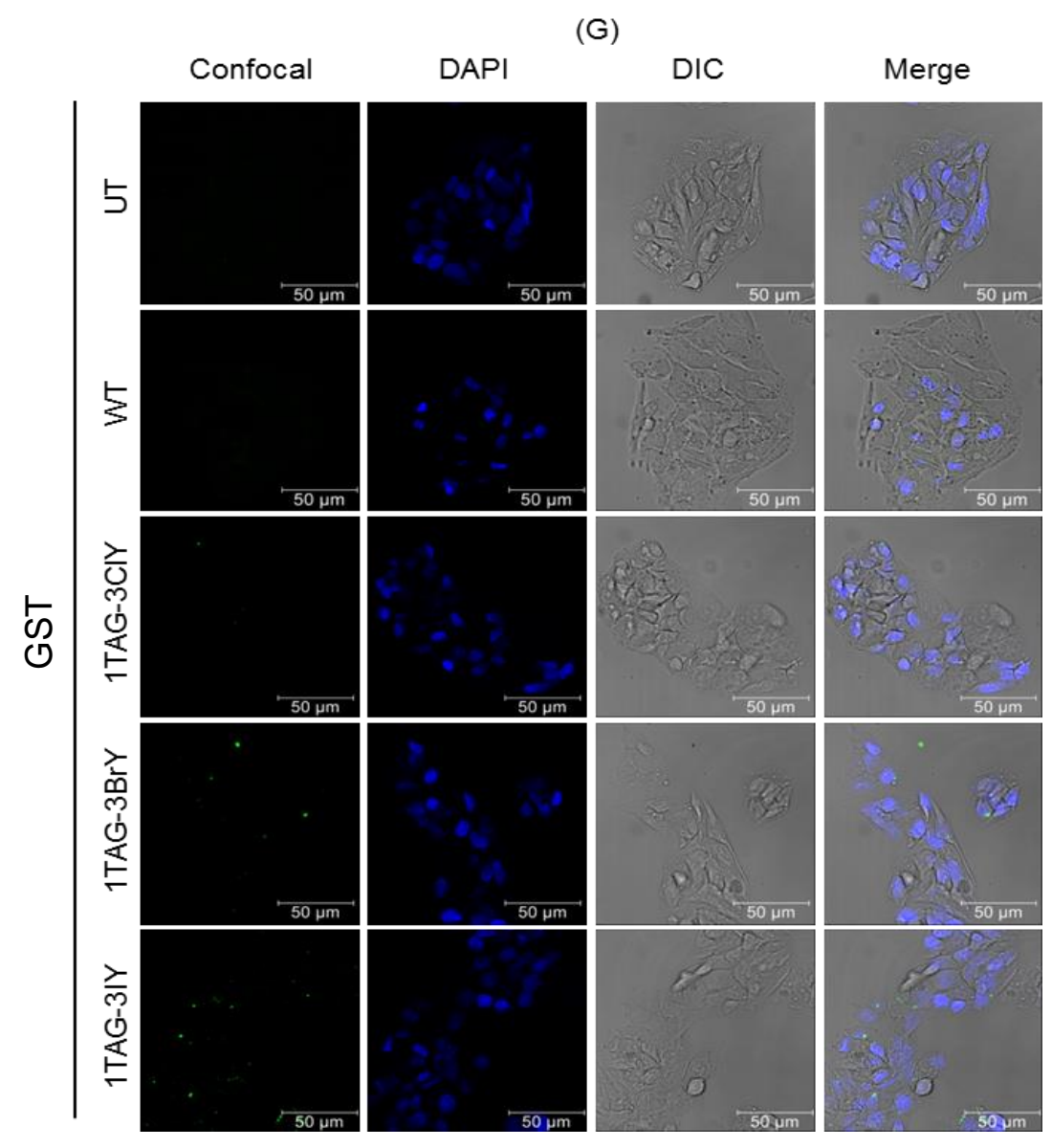

Figure S14: Confocal images of internalization and distribution of halo-EmGFP $(1 \mu \mathrm{M})$ having 3-IY in positions 39 (1TAG) at $37^{\circ} \mathrm{C}$ (A) (or) $4{ }^{\circ} \mathrm{C}$ (or) under ATP depletion (or) after pre-treatment with MCT8 inhibitor or endocytosis inhibitors in HepG2 cells. 


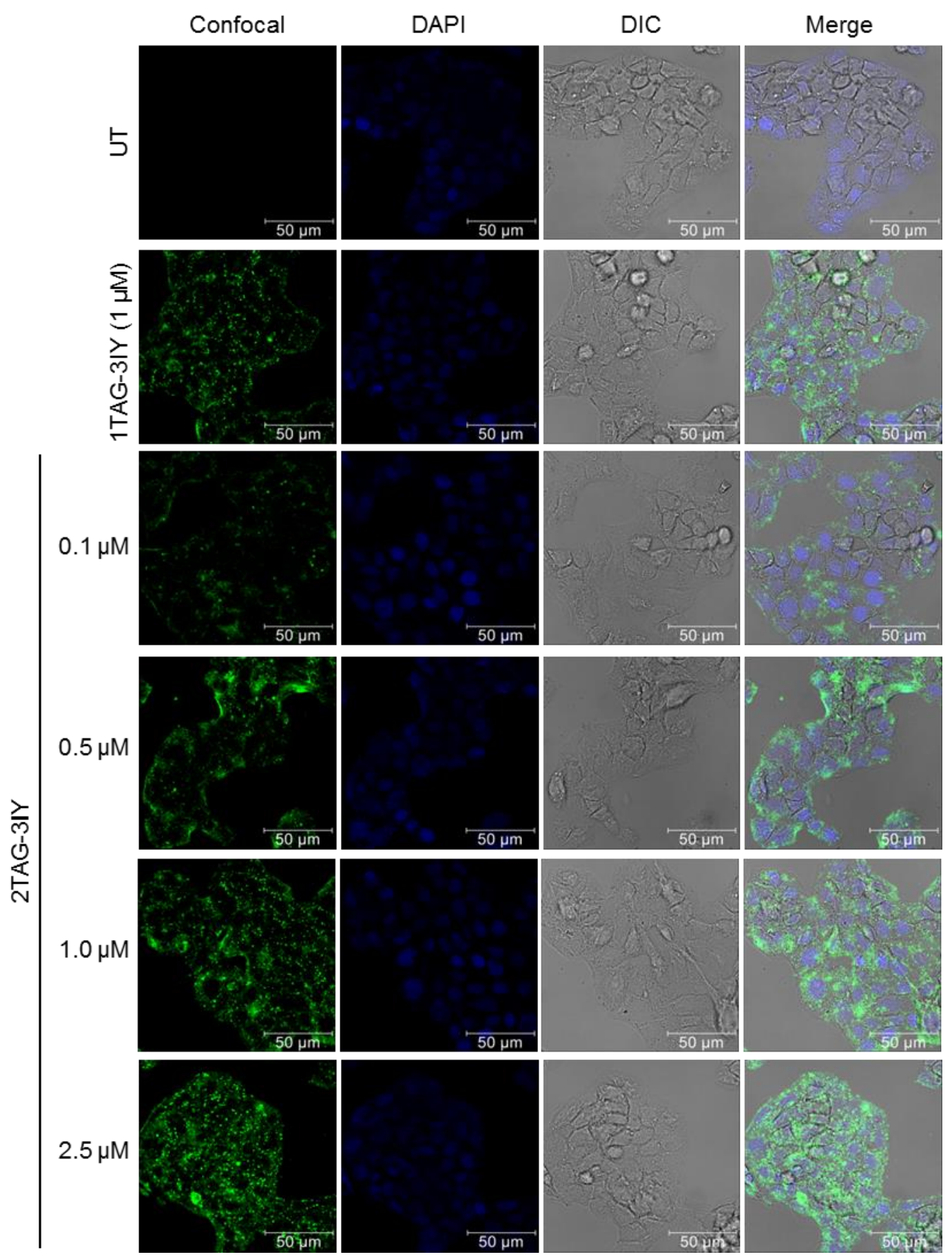

Figure S15: Confocal images of HepG2 cells treated with various concentrations of halo-EmGFP (2TAG) for $90 \mathrm{~min}$. 
(A)
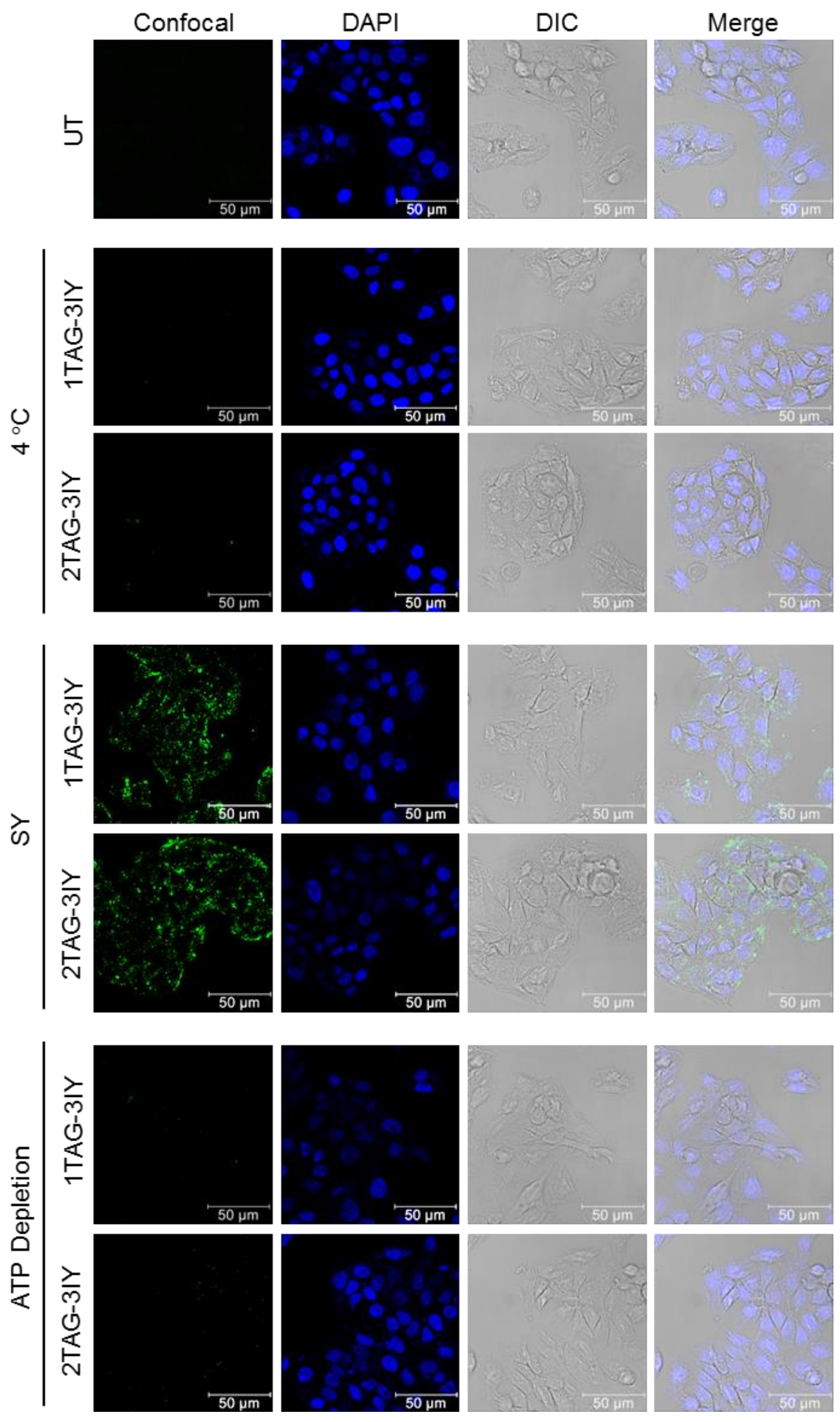
(B)
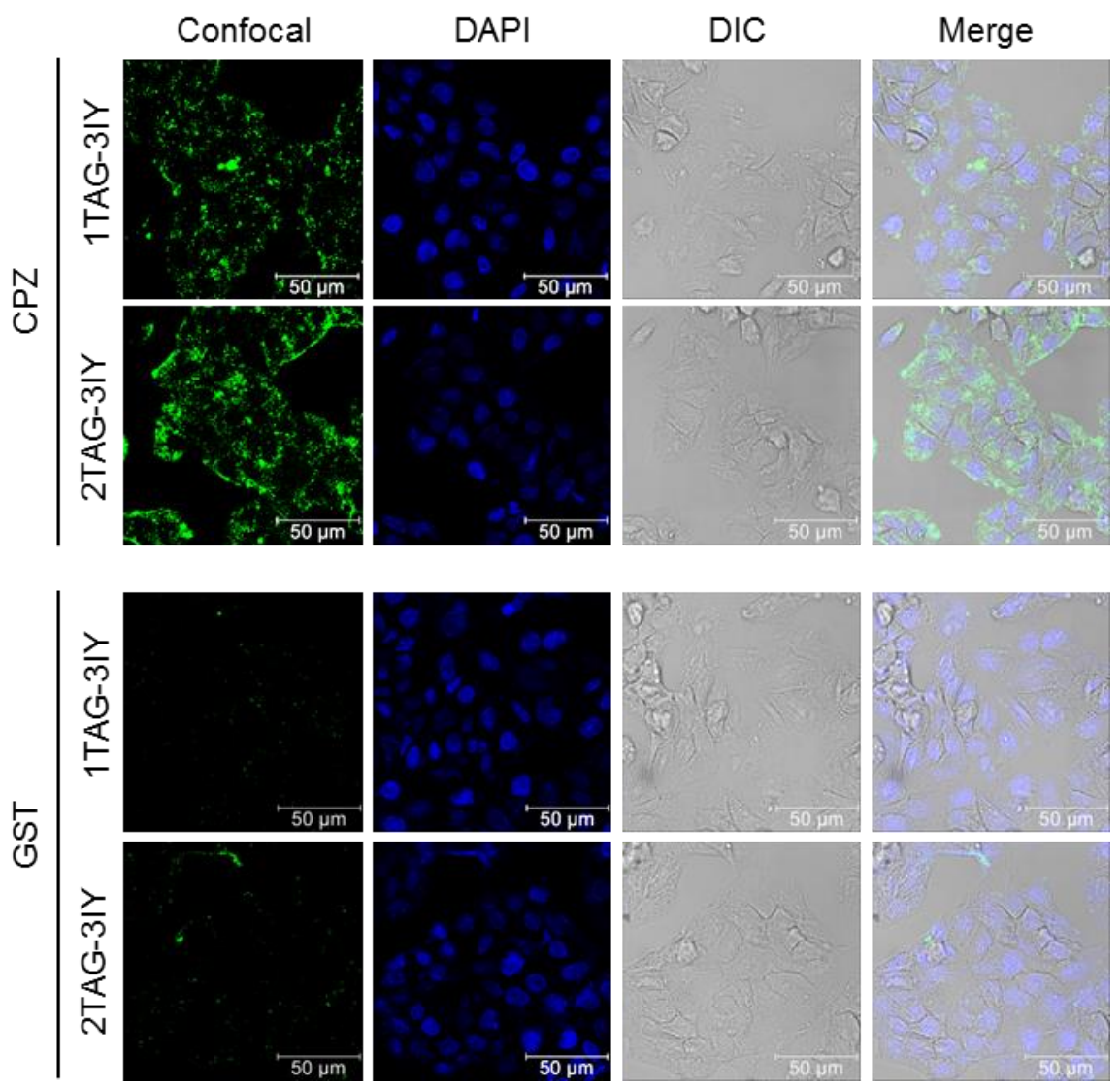

Figure S16: Confocal images of internalization and distribution of halo-EmGFP-2TAG $(1 \mu \mathrm{M})$ at $37^{\circ} \mathrm{C}$ (or) $4{ }^{\circ} \mathrm{C}$ (or) under ATP depletion (or) after pre-treatment with MCT8 inhibitor or endocytosis inhibitors in HepG2 cells (A \& B). 


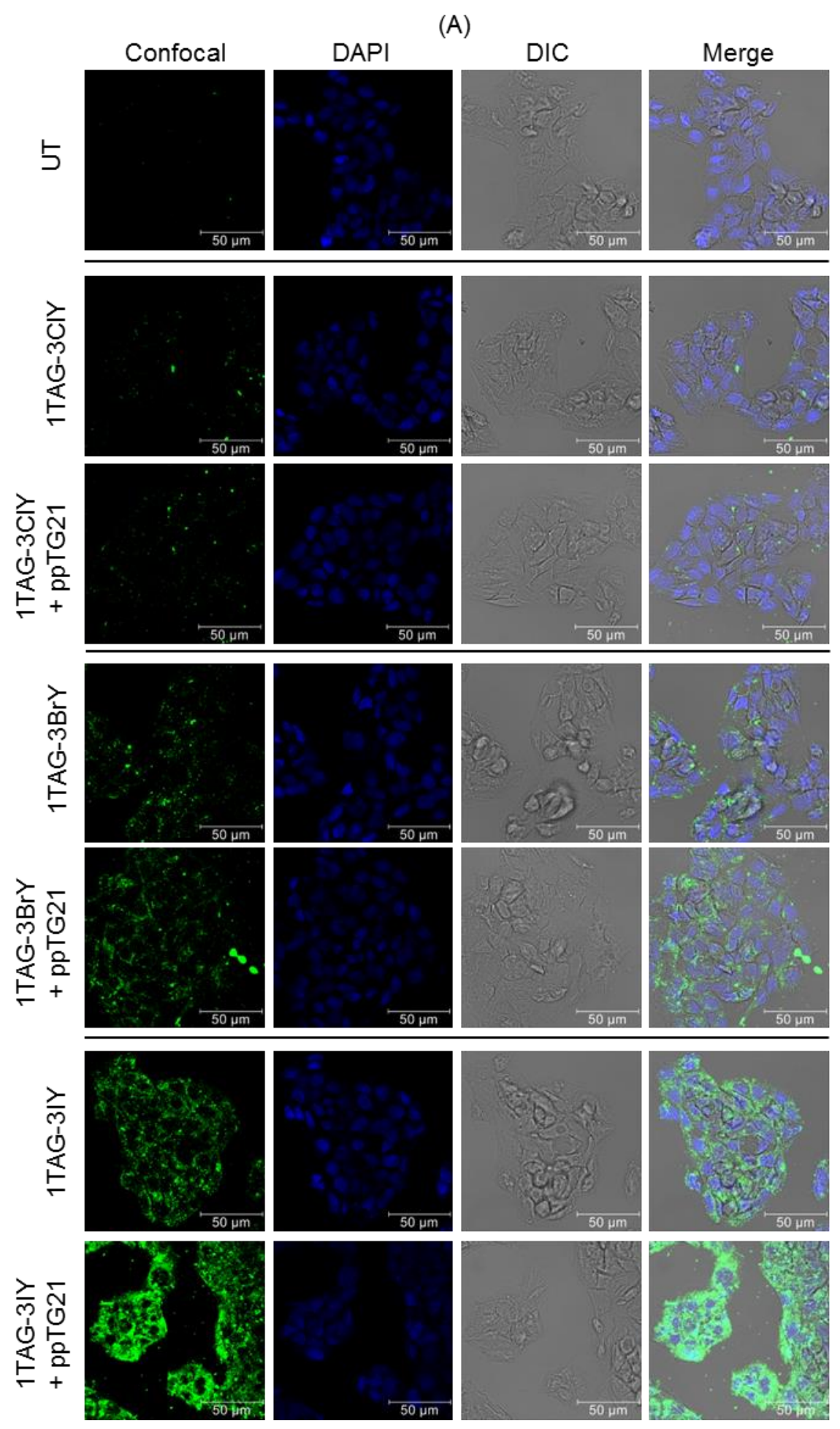




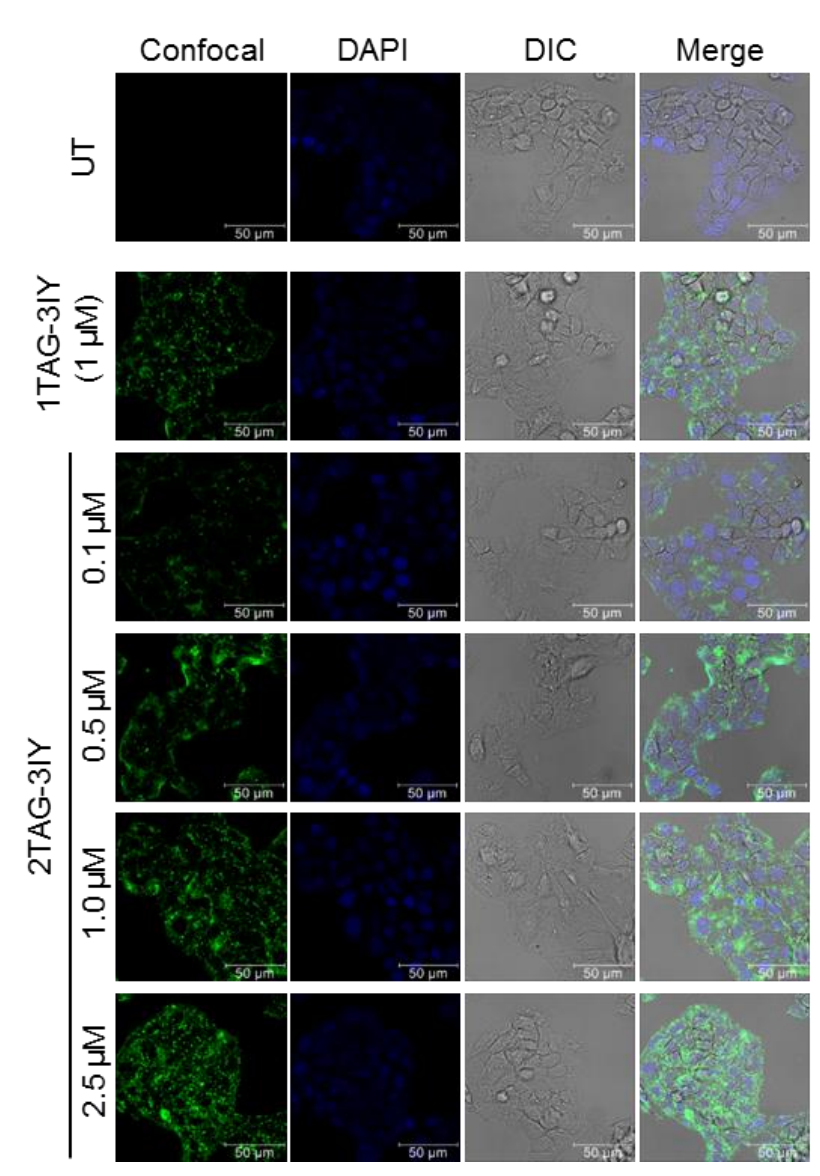

(B)
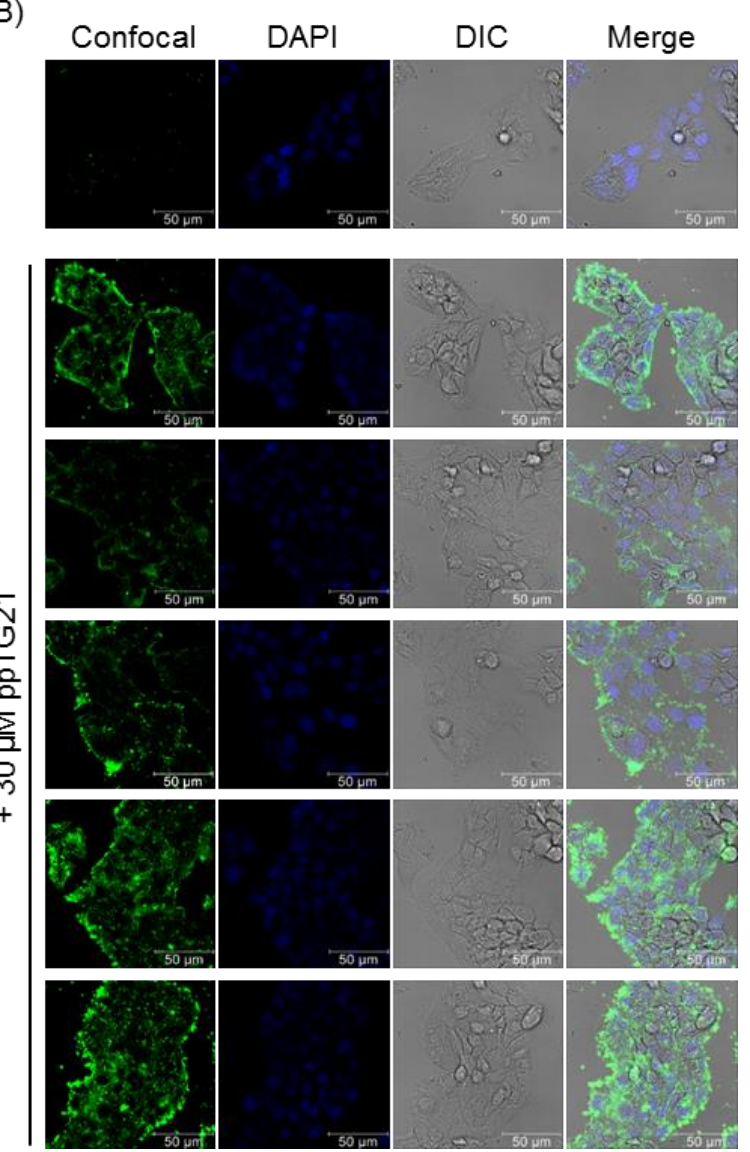

(C)

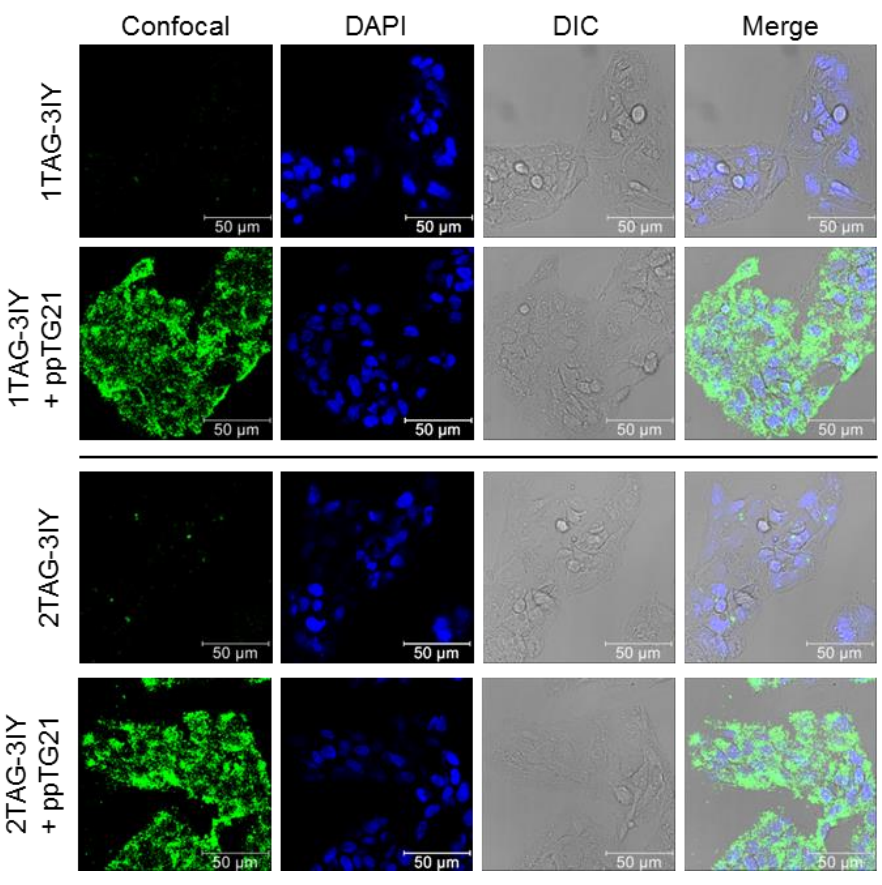

Figure S17: Confocal images of HepG2 cells after $90 \mathrm{~min}(\mathrm{~A} \& \mathrm{~B})$ or $24 \mathrm{~h}(\mathrm{C})$ of co-treatment with 1 $\mu \mathrm{M}$ halo-EmGFP and $30 \mu \mathrm{M}$ ppTG21. 
(A)

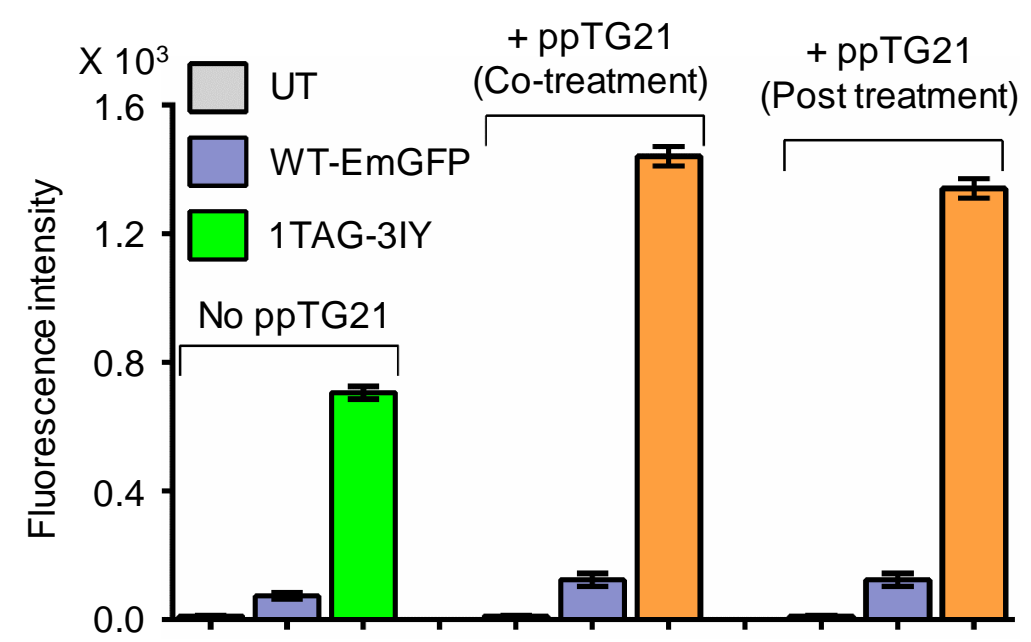

(B)

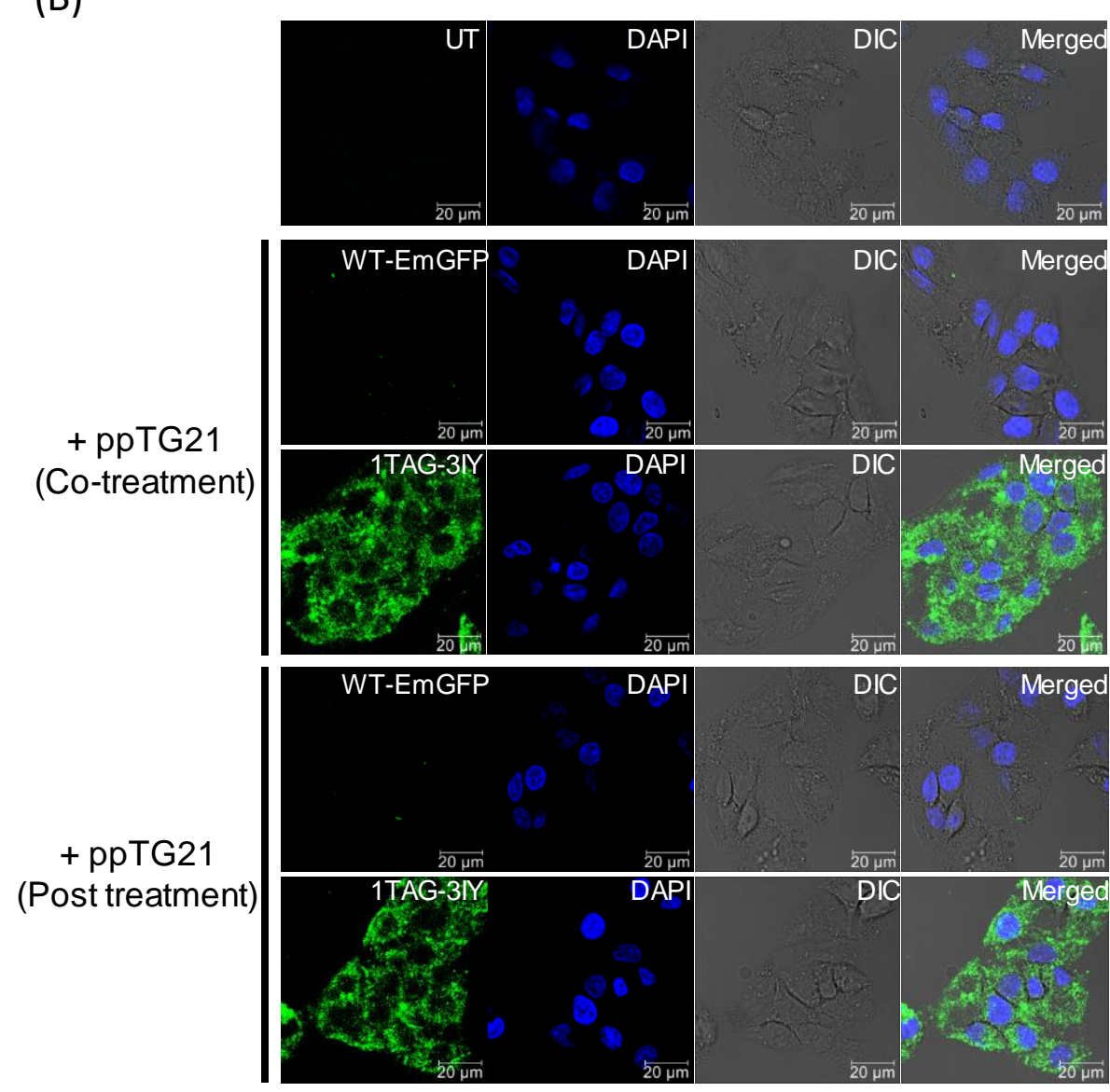

Figure S18: $(A)$ The fluorescence measured by a plate reader after 60 min co-treatment of HepG2 cells with $1 \mu \mathrm{M}$ of $1 \mathrm{TAG}-3 \mathrm{YY}$ EmGFP and $30 \mu \mathrm{M}$ of ppTG21 at $37{ }^{\circ} \mathrm{C}$. For the post-treatment of ppTG21, the cells were washed thoroughly with PBS buffer after 60 min and then treated with 30 $\mu \mathrm{M}$ ppTG21 for $30 \mathrm{~min}$. (B) The confocal images obtained after 60 min co-treatment of HepG2 cells with $1 \mu \mathrm{M}$ of $1 \mathrm{TAG}-3 \mathrm{IY}$ EmGFP and $30 \mu \mathrm{M}$ of ppTG21 at $37^{\circ} \mathrm{C}$. For the post-treatment of ppTG21, the cells were washed thoroughly with PBS buffer after 60 min and then treated with $30 \mu \mathrm{M}$ ppTG 21 for $30 \mathrm{~min}$. In all experiments, the cells were washed with PBS buffer containing heparin $(1 \mathrm{mg} / \mathrm{mL})$ to remove surface-bound proteins. 


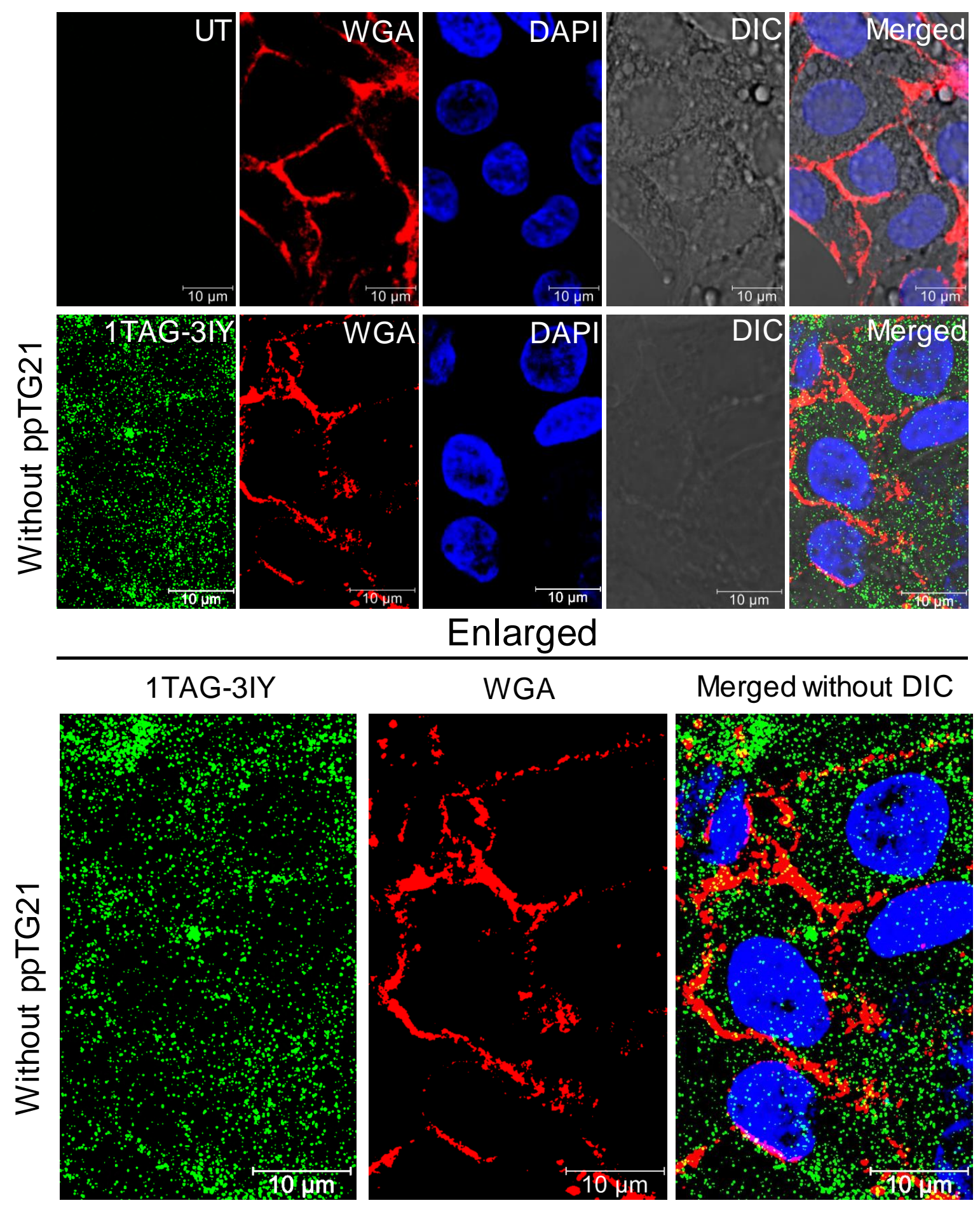

Figure S19: Confocal images of HepG2 cells after treatment with the plasma membrane tracker (wheat germ agglutinin, WGA, $5 \mu \mathrm{g} / \mathrm{mL}, 10$ min incubation time) or $1 \mu \mathrm{M}$ 1TAG-3IY-EmGFP for 60 min without ppTG21. In all experiments, the cells were washed with PBS buffer containing heparin (1 $\mathrm{mg} / \mathrm{mL}$ ) to remove surface-bound proteins. 
(A)

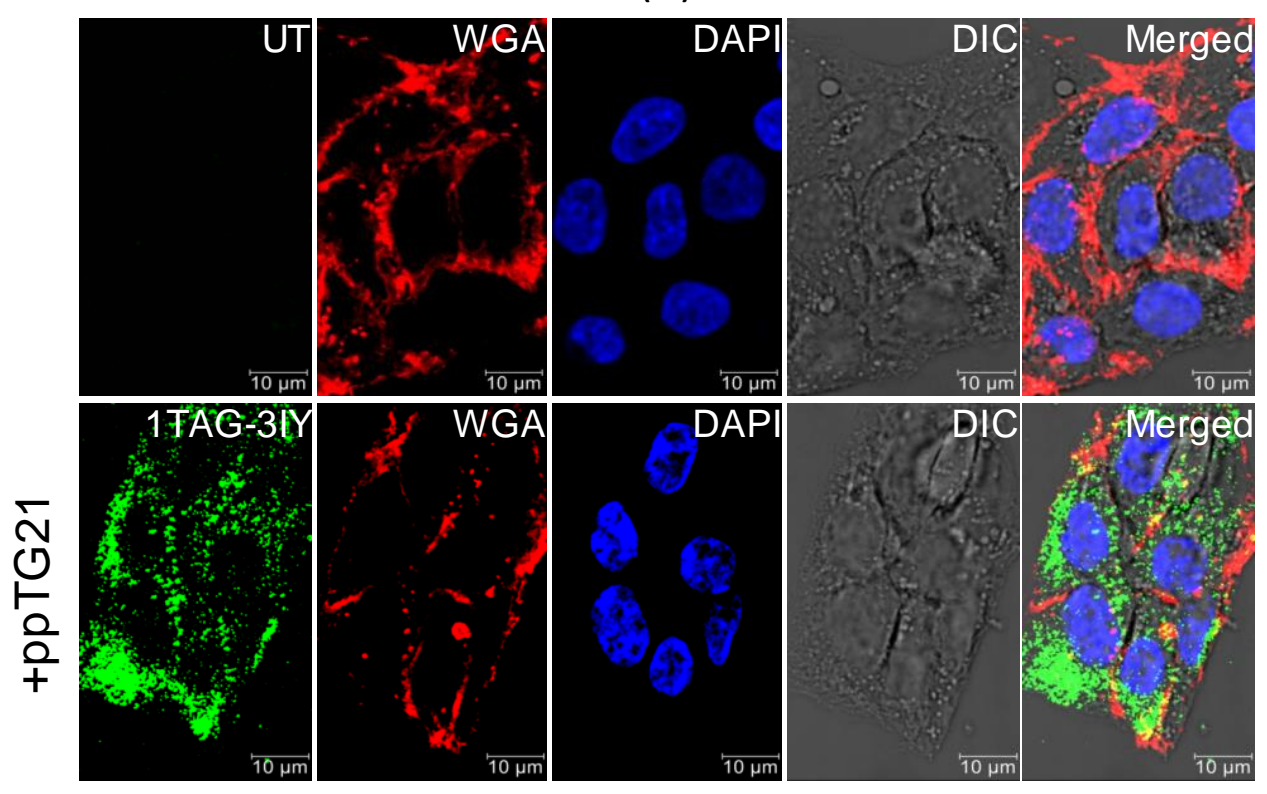

(B)
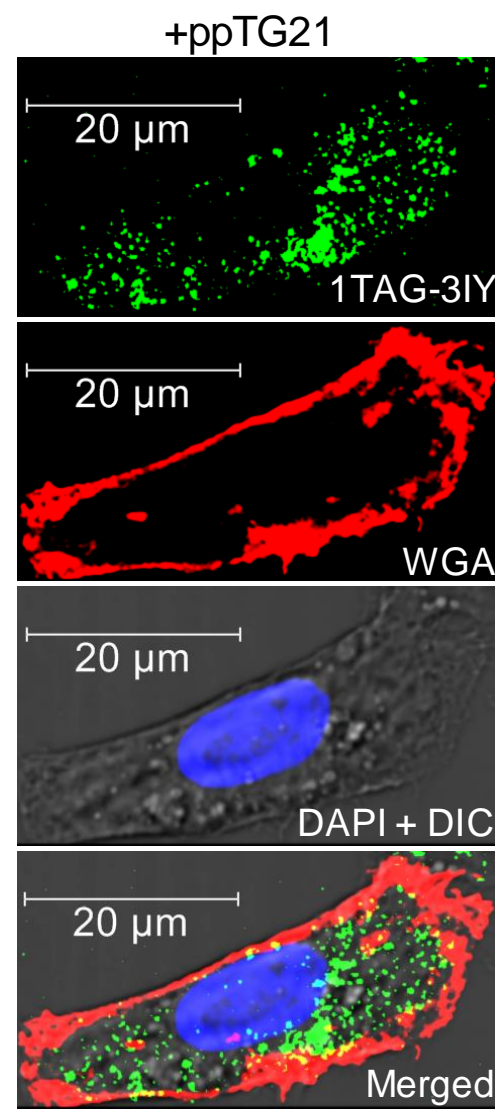

Figure S20: Confocal images of HepG2 cells after treatment with $1 \mu \mathrm{M}$ 1TAG-3IY-EmGFP for 60 min, followed by washing with PBS buffer and then treatment with $30 \mu \mathrm{M}$ ppTG21 for 30 min. For staining the plasma membrane and nucleus, wheat germ agglutinin (WGA, $5 \mu \mathrm{g} / \mathrm{mL}, 10 \mathrm{~min}$ incubation time) and DAPI (300 nM, 10 min incubation time), were used respectively. In all experiments, the cells were washed with PBS buffer containing heparin $(1 \mathrm{mg} / \mathrm{mL})$ to remove surface-bound proteins. 


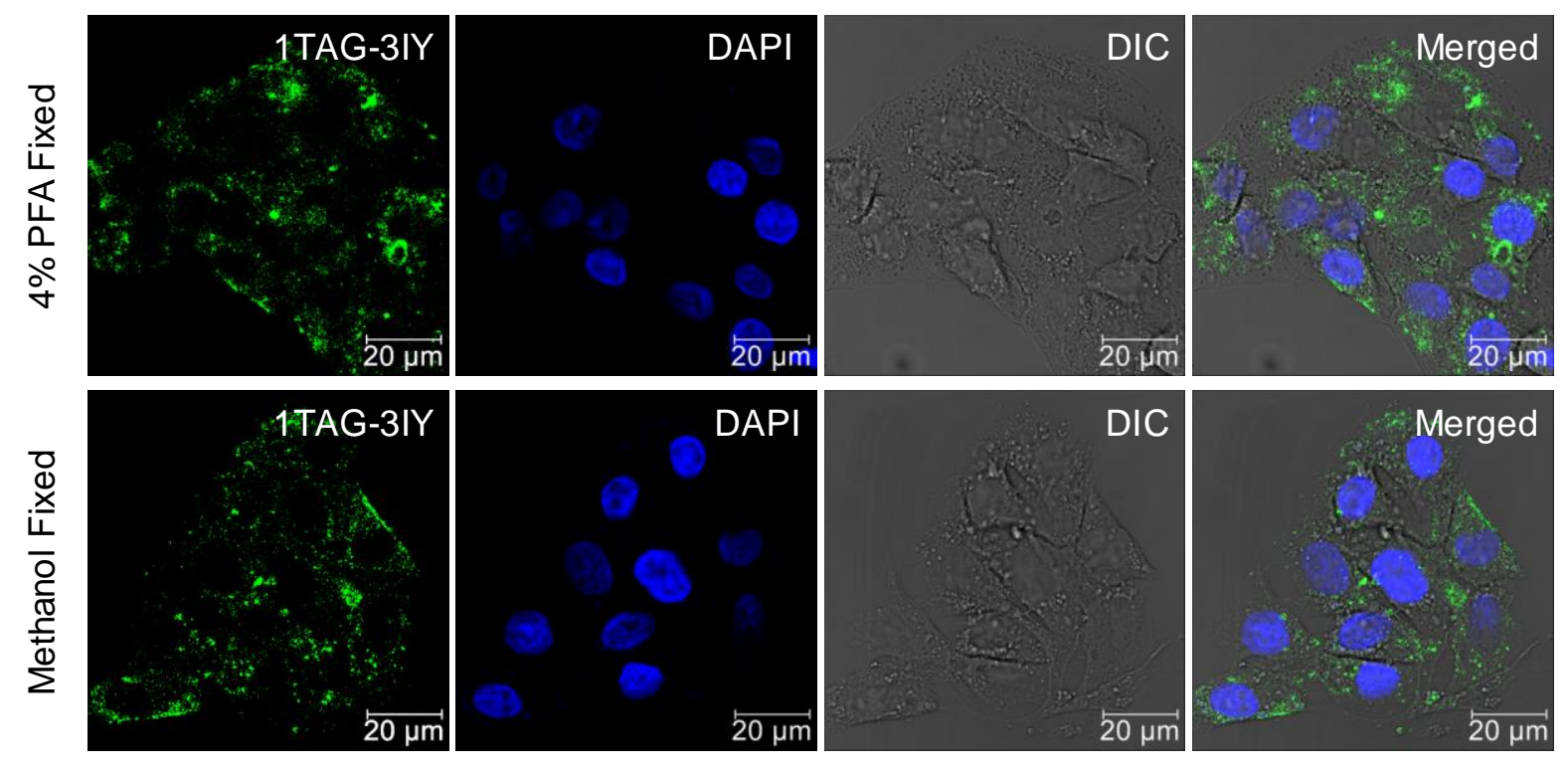

Figure S21: Confocal images of HepG2 cells after 90 min of treatment with $1 \mu \mathrm{M} 1 \mathrm{TAG}-3 \mathrm{YY}-\mathrm{EmGFP}$. Fixing the cells with two different methods gave identical results.

\section{References}

[1] R. S. Phillips, S. Busby, L. Edenfield, K. Wickware, Amino Acids 2013, 44,529-532.

[2] J. M. Collins, K. A. Porter, S. K. Singh, G. S. Vanier, Org. Lett. 2014, 16, 940-943.

[3] T. S. Young, I. Ahmad, J. A. Yin, P. G. Schultz, J. Mol. Biol. 2010, 395, 361-374.

[4] K. Sakamoto, K. Murayama, K. Oki, F. Iraha, M. Kato-Murayama, M. Takahashi, K. Ohtake, T. Kobayashi, S. Kuramitsu, M. Shirouzu, S. Yokoyama, Structure 2009, 17, 335-344.

[5] T. Kobayashi, O. Nureki, R. Ishitani, A. Yaremchuk, M. Tukalo, S. Cusack, K. Sakamoto, S. Yokoyama, Nat. Struct. Biol. 2003, 6, 425-432.

[6] J. Wang, J. Xie, P. G. Schultz, J. Am. Chem. Soc. 2006,128, 8738-8739.

[7] a) M. J. Lajoie, A. J. Rovner, D. B. Goodman, H. R. Aerni, A. D. Haimovich, G. Kuznetsov, J. A. Mercer, H. H. Wang, P. A. Carr, J., A. Mosberg, N. Rohland, P. G. Schultz, J. M. Jacobson, J. Rinehart, G. M. Church, F. J. Isaacs, Science 2013, 342, 357-360; b) Z. J. Chen, Z. Tian, K. Kallio, A. L. Oleson, A. Ji, D. Borchardt, D. E. Jiang, S. J. Remington, H. W. Ai, J. Am. Chem. Soc. 2016, 138, 4900-4907.

[8] H. Ungati, V. Govindaraj, G. Mugesh, Angew. Chem. Int. Ed. 2018, 57, 8989-8993. 